Engineering History and Heritage Volume 166 Issue EH4

Collapse of a cable-stayed road bridge in Germany in 1825

Birnstiel
Proceedings of the Institution of Civil Engineers Engineering History and Heritage 166 November 2013 Issue EH4 Pages 207-226 http://dx. doi.org/10.1680/ehah.13.00007 Paper 1300007

Received 04/03/2013

Published online 05/10/2013

Keywords: bridges/cables and tendons/failures

\title{
Collapse of a cable-stayed road bridge in Germany in 1825
}

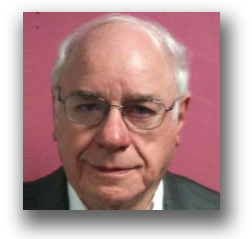

Charles Birnstiel MCE, EngSCD, PE, FICE, FASCE

Principal Associate, Hardesty \& Hanover, LLC, New York, USA

On 6 December 1825 a cable-stayed road bridge at Nienburg-on-the-Saale, Germany, collapsed with the loss of 55 lives. It was the first cable-stayed bridge with a roadway for team-drawn wagons and with two sidewalks for pedestrians and spanned $79 \mathrm{~m}$ between towers, with a double-leaf bascule at midspan to permit passage of sailing vessel masts. The disaster contributed to the negative attitude towards bridges supported by a multiplicity of tensile stays, which persisted until after World War II. As Nienburg recovered from the Napoleonic Wars it needed a bridge across the Saale but a conventional masonry arch bridge was unaffordable. A local building official, Gottfried Bandhauer, proposed a cable-stayed design. There were serious quality control problems during construction, but the bridge was tested and opened to traffic in September 1825. It collapsed 3 months later during a celebration honouring the Duke. The bridge structure, the events leading to the collapse, and the post-collapse investigations are related in this paper, including results of approximate static and dynamic analyses. The purpose of this paper is to relate the history of the bridge and the consequences of engineering designs that are too advanced for the artisans at the time and place.

\section{Introduction}

During the evening of 6 December 1825 a cable-stayed road bridge across the Saale River at the City of Nienburg in the present Land (state) of Sachsen-Anhalt, Germany, collapsed with the loss of 55 lives. The collapse occurred 3 months after the bridge was approved for service, during a torch-light celebration intended to thank the Duke of Anhalt-Cöthen for enabling its construction. The disaster was cited as contributing to the 125 year hiatus in cable-stayed fixed bridge construction until after World War II (Leonhardt and Zellner, 1970). The Nienburg Bridge was the first cable-stayed bridge with a carriageway for heavy team-drawn wagons and two sidewalks for pedestrians and was probably the first with a fan arrangement of both forestays and backstays. Although it was the largest cable-stayed bridge built up to that time, and so many people died and/or were injured, little was published about the disaster in the nascent technical press (Chrimes, 1985). Cable-stayed bridge failures were discussed by Drewry (1832) and Bender (1868) but neither mentioned the Nienburg Bridge. The most readable account of the collapse is that of Vogel (1986) because it was written in modern German. However, Vogel relied heavily on Siebert (1900), a grandson of William Nagel, a public official in Nienburg and a strong proponent and continuous supporter of the bridge project. Nagel was one of the first to die in the collapse, from a head injury due to falling wrought iron stays. Writing 75 years after the event, Siebert had access to information saved by his family and to the reports published by the bridge's designer, Christian Gottfried Heinrich Bandhauer.

\section{The bridge proposal}

In 1823 Nienburg was a city of about 2000 population located in the small duchy of Anhalt-Cöthen, a member of the German Confederation that was formed following the Napoleonic Wars by the Congress of Vienna in 1815. The Confederation comprised between 39 and 41 entities (the number varied during the period 1815-1835) at least three of which were governed by other non-German-speaking countries, including Great Britain. As shown in Figures 1 and 2, the city lies west of the Saale River, just south of where the Saale discharges into the Elbe River. The area was recovering economically from the French military occupation of 1806-1813, although French political influence remained for decades after the French withdrew following Napoleon's defeat at Leipzig in October 1813, during the War of Liberation. Commerce at Nienburg increased and it became an inland port and transportation centre due mainly to rapid industrialisation in Great Britain during the reign of George IV, which caused the cottage textile industry in central Germany to become redundant because of cheaper British imports. The citizens clamoured for a permanent fixed crossing of the Saale River to replace the boat ferry that had been in use since an earlier bridge succumbed during the Thirty Years' War. However, the cost of typical contemporary masonry arch bridges such as depicted 


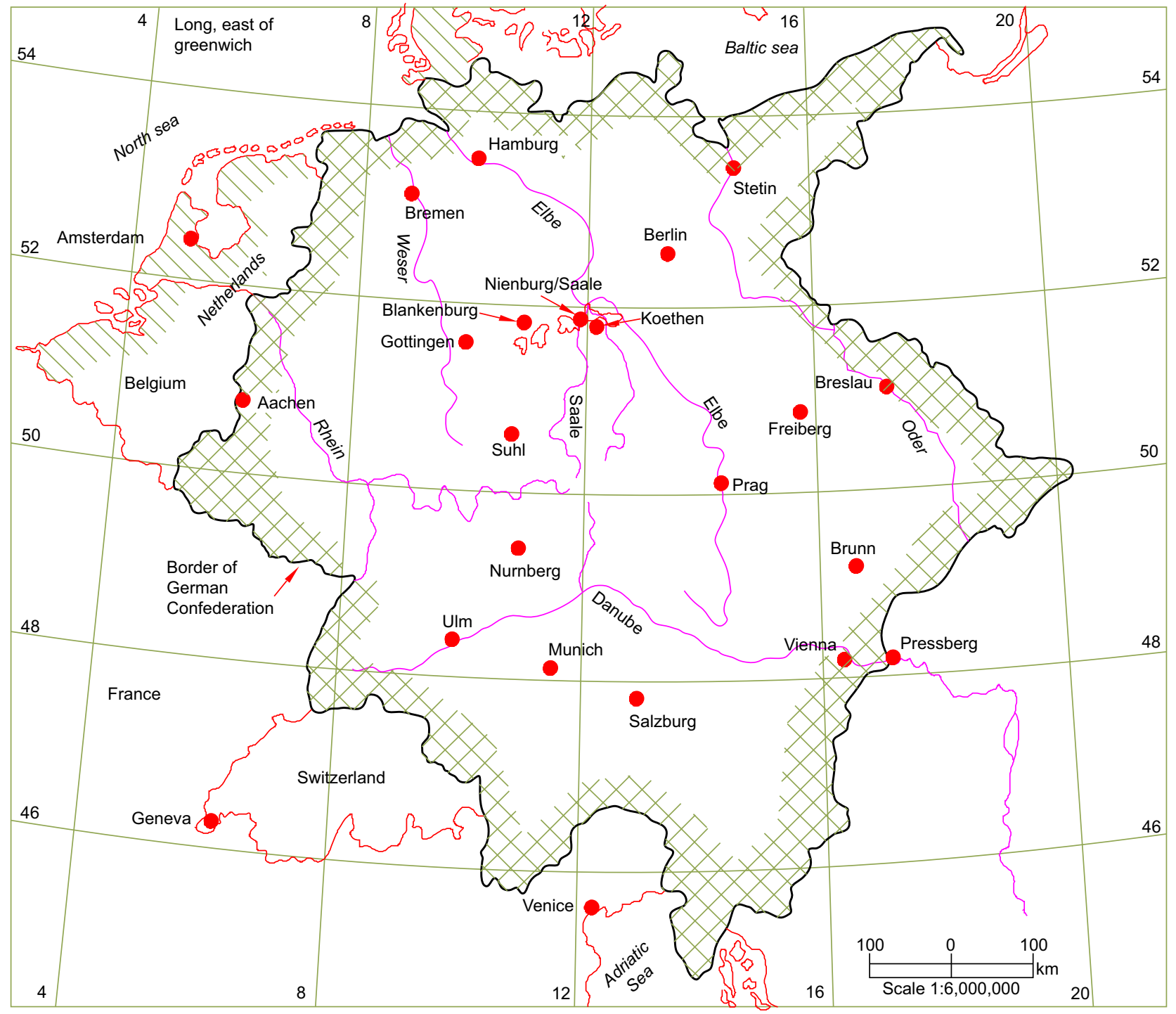

Figure 1. German Confederation in 1823. Source: Birnstiel, after Droysens Allgemeiner Historischer Handatlas (Droysens, 1886)

in Wilmers (2012) was prohibitive because of Anhalt-Cöthen's precarious financial situation. Besides, an arch bridge would have been opposed by navigators because the masts of sailing vessels would have had to be unshipped to enable the vessels to proceed upstream of the bridge, and then reinstalled, a nuisance for navigators.

At a meeting of the ducal finance office (Herzogliche Rentkammer) on 10 January 1824, Bandhauer presented his concept for bridging the Saale at Nienberg. The officials responded that his proposal had much merit, especially if the bridge could be built for 4000 Thaler. In a public meeting only a few days thereafter, on 14 or 15 January 1824 , he displayed sketches and drawings of his proposed design. Figure 3 is his oblique perspective drawing of the bridge (Bandhauer, 1827b). He wrote that he had selected the cable-stayed type of cablesupported bridge for reasons of economy and stiffness and estimated the construction cost at 4000 Thaler. At the meeting there was general approval of his proposal but funds for building during the coming year had already been committed for other important work, whereupon ten attendees offered to advance the 4000 Thaler as a loan to the city (really to the Duke) with the proviso that it be repaid at the rate of 1000 Thaler per year, with interest. It may seem unusual that citizens 
Engineering History and Heritage

Volume 166 Issue EH4
Collapse of a cable-stayed road

bridge in Germany in 1825

Birnstiel

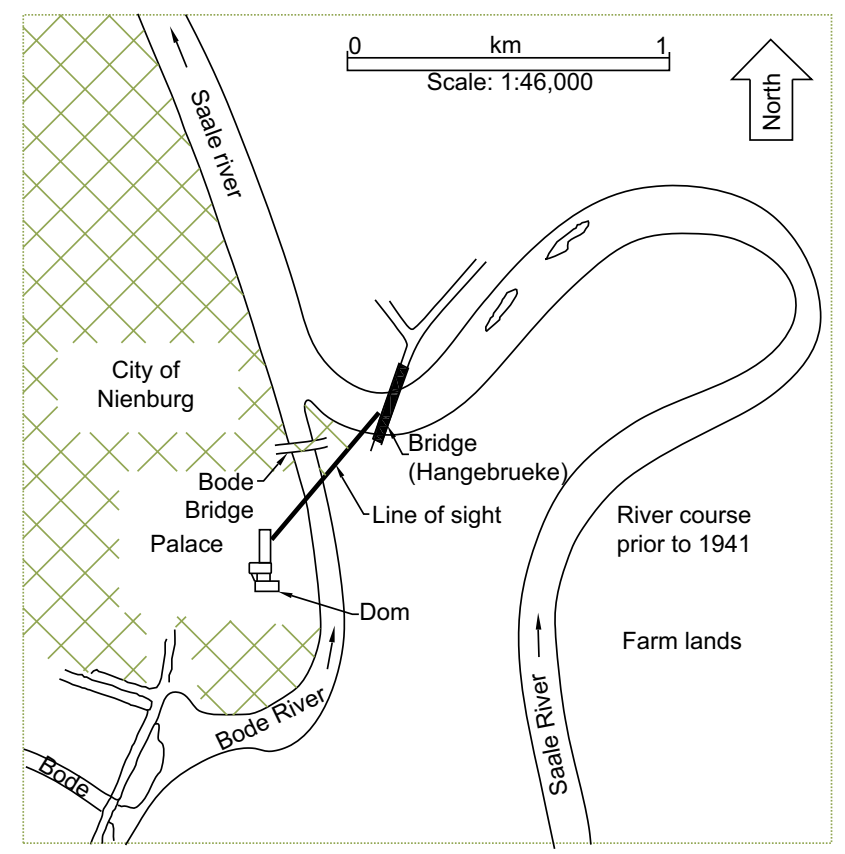

Figure 2. Nienburg-an-der Saale. Source: Birnstiel, after topographic maps dated 1853 and 1941

offered the Duke a loan inasmuch as absolutism was restored in the Germanic states after the Napoleonic era. However, it was not the absolutism of Louis XIV (the Sun King) and the early Louis XVI, but a modified form. Why did Duke Ferdinand not simply raise taxes and order the bridge built? It seems that after 1815 some of the German Confederation nobles, including Duke Ferdinand, realised that government had to become more liberal, with more involvement of citizens in decision making. Among the ten men who loaned money was a legal official named William Nagel, who offered 500

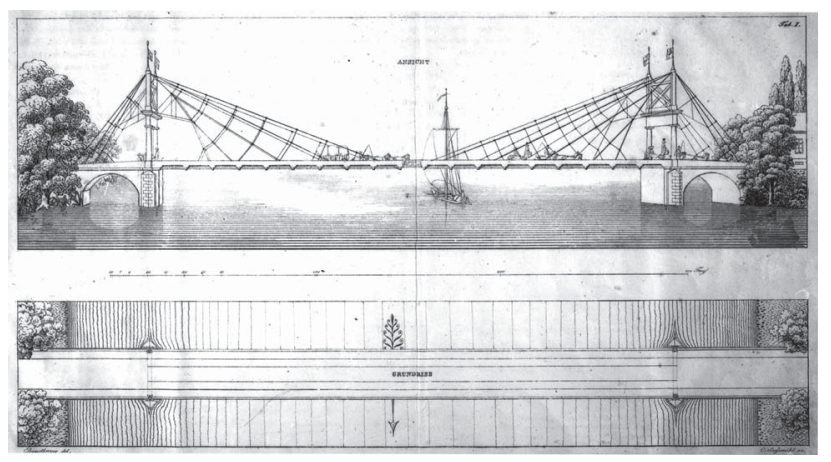

Figure 3. Oblique perspective of the Nienburger Hängebrücke. Source: Birnstiel, from microfilm of Bandhauer (1827b), courtesy Sächsische Landesbiblioteck Dresden, DDR
Thaler (Bandhauer, 1829: p. 17). Nagel was one of the first to die in the disaster.

Bandhauer had the title 'Baurat' in the dwarf state of AnhaltCöthen at the time he proposed the cable-stayed bridge. 'Baurat' is difficult to translate; sometimes it is taken as 'a person in charge of planning and building control'. He was in charge of construction ordered by the absolutist ruler Duke Ferdinand, but also did non-public projects in which he served as designer/builder.

As the bridge's designer he was the architect, and in the age before engineering was separated from architecture, also the engineer. More than that, he also oversaw the construction, acting as a construction manager. After the collapse Bandhauer published reports that included his drawings and computations, correspondence, and his defence against legal charges (Bandhauer, 1827a, 1827b, 1829). They were quite thorough and technically adequate, considering the backwardness of industry (and hence engineering) in the early German Confederation compared to that of Britain (Lee, 2011). Bandhauer's works contained all the technical information known to the author until he came across (many years after starting this research) an unsigned inspection report of a Prussian master builder in March 1825, written before the collapse, but not published until after the collapse (Birnstiel, 2005). The anonymous report in Beuth (1826) casts doubt on some aspects of Bandhauer's writing.

Another source about Bandhauer and the bridge collapse is the biography written by Nestler (1996). He devotes five pages to the Nienburg Bridge, based mostly on Siebert (1925) and on Bandhauer (1829).

\section{Development of cable-supported bridges up to 1824}

Figure 4 shows the four types of cable-supported bridges; taut ribbon, suspension, suspension with cable stays, and cablestayed.

The taut iron-chain ribbon bridges of China were known in Germany through Leupold (1736). That concept was used by Johann Ludwig Leidner for building a taut chain bridge to support water pipes across the Lahn River at Weilburg in the present Land of Hessen, Germany, which was completed in 1785. It comprised eight wrought iron rod chains of 1.5 Zoll $(3.8 \mathrm{~cm})$ diameter that were stretched horizontally between massive basalt abutments $40 \mathrm{~m}$ apart (Berg, 1824). No information as to the chain sag at any stage of the bridge life is available, but the sag ratio must have been small, based on the photo in Schnell (1933), which was taken before the bridge was demolished in 1934. 


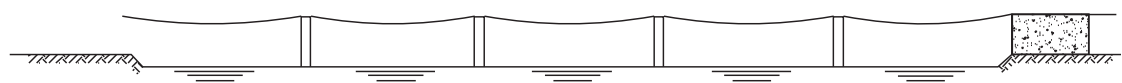

(a) Taut ribbon bridge

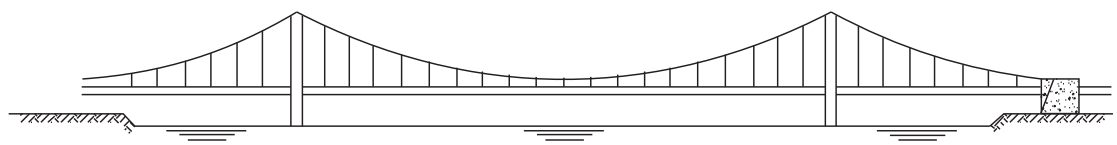

(b) Suspension bridge

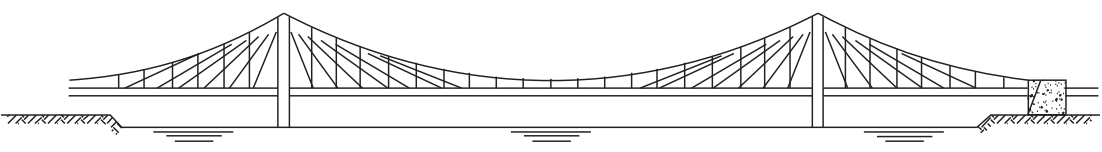

(c) Suspension bridge with cable stays

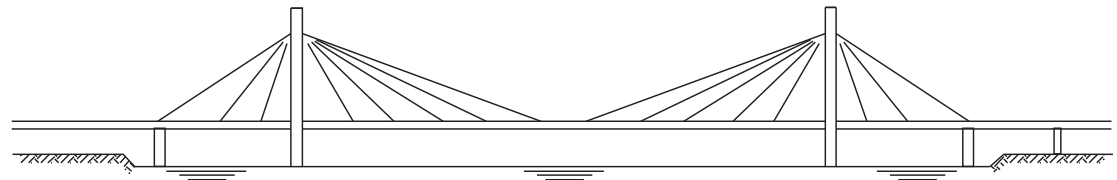

(d) Cable - stayed bridge

Figure 4. Types of cable-supported bridges

The chain links were wrought iron rods with eye ends, and most end connections were made by forging after inserting an uncompleted eye through a completed eye. The links at the end of each chain were threaded in order that they could be tensioned by nuts on the far sides of the abutments (W. Einsingbach, 1975, private communication of manuscript proof sheets).

The eight chains were uniformly spaced horizontally in the lateral direction and covered with wood planks giving a bridge floor $2.4 \mathrm{~m}$ wide. A covered rectangular trough was built on the floor. This was not an open-channel aqueduct; four lead pipes of 2 Zoll $(10 \mathrm{~cm})$ diameter were embedded in the trough with straw and soil for insulation. So it was a pressurised aqueduct, not an open-channel aqueduct, and hence its bottom slope was immaterial.

Bandhauer probably knew of the Weilburg Bridge; Weilburg and Nienburg are only about $275 \mathrm{~km}$ distant, but he realised that a ribbon bridge suitable for supporting a constant load would not be suitable at Nienburg because of the heavy vehicle loads in Nienburg traffic.

Early concepts for cable-stayed bridges, including those of Faustus Verantius, were reviewed by Svensson (2012). A drawing of a combined cable-stayed and suspension bridge by Verantius is available in Parsons (1939).
The cable-stayed bridge concept appears to have reached Germany from Britain through a translation of Stevenson's 1821 paper (Stevenson, 1822). Figure 5 is a reproduction of Plate V in Stevenson (1822). Examples of the four basic types of cable-supported bridges are shown; Stevenson Fig. V-1, the Winch Bridge, a ribbon (or band) type; Fig. V-2, the King's Meadow Bridge, a cable-stayed bridge; Fig. V-3, a combined stayed and suspension bridge at Dryburgh Abbey (the second bridge at the site); and Fig. V-4, the Union Bridge over the Tweed, a suspension bridge. Both the bridges at King's Meadow and Dryburgh Abbey were pedestrian bridges, not adequate for team-drawn wagons. That at Dryburgh was only $4 \mathrm{ft}(1 \cdot 22 \mathrm{~m})$ wide for its full length.

The King's Meadow Bridge was built in the summer of 1817. It had a span of $110 \mathrm{ft}(33.6 \mathrm{~m})$ and a deck $4 \mathrm{ft}(1.2 \mathrm{~m})$ wide. There was a total of ten pairs of stays of no. 1 wire (Ruddock, 1999).

It is of interest that the original Dryburgh Abbey Bridge was fully cable stayed; it did not have a catenary suspension cable (Stevenson, 1821: p. 241, 1822: p. 119). It was designed and built in 1817 by Messrs Smith (Smith, 1836) and blew down in a great storm of 1819 . Smith wrote 'The span as executed was 261 feet between points of suspension. The longest chains were 1 inch in diameter, and they diminished as they shorted to half an inch. The links were about 10 feet long.... We restored it 


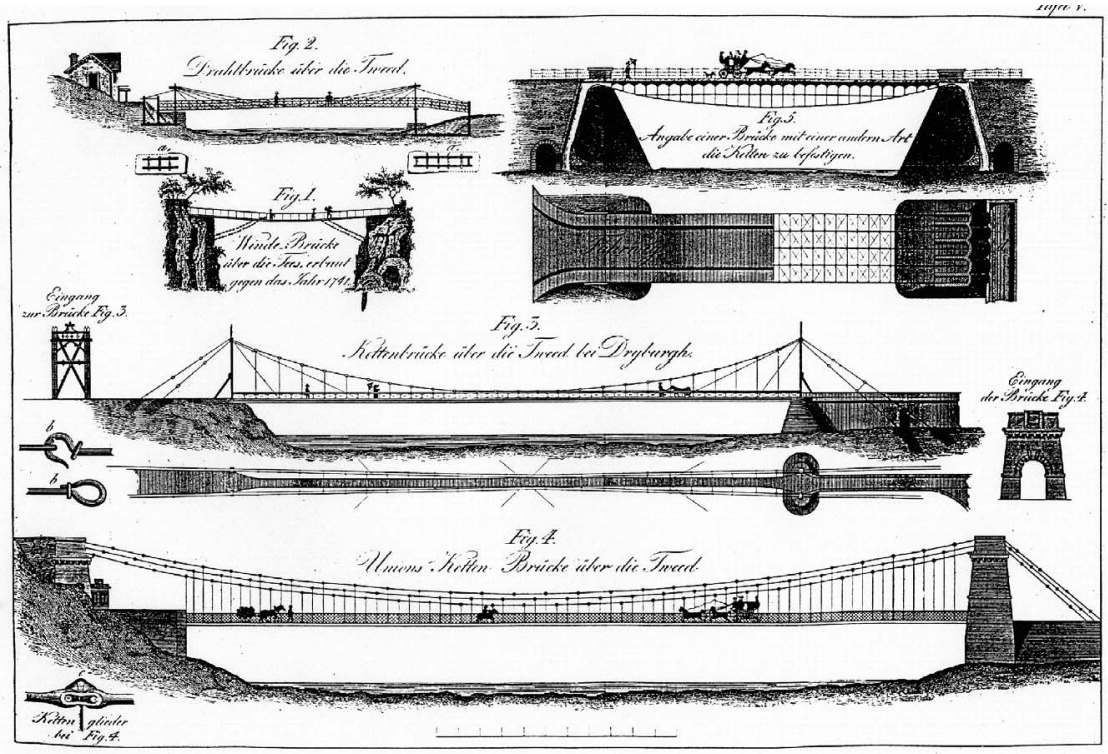

Figure 5. Plate $\vee$ of Stevenson (1822). Source: Birnstiel

(the bridge) in the summer of $1819 \ldots$ The main suspending chains are now four in number, two on each side, $13 / 8$ inch diameter... They are hung in the catenarian plan, and have perpendicular suspenders...' (Smith, 1836).

The first Dryburgh Abbey bridge vibrated noticeably under foot traffic due to the looseness of the diagonal chains. According to Stevenson (1821: p. 244) 'three or four persons, who were very improperly amusing themselves, by trying the extent of this motion, produced such an agitation in all its parts, that one of the longest of the radiating chains broke near the point of suspension' - a harbinger of the Nienburg event.
The bridge had a life of 6 months; it collapsed during a storm on 15 January 1818 (Ruddock, 1999).

Later, Navier was commissioned by the French government to travel to England and Scotland to study their cable-supported bridges (Kurrer, 2008). He quoted Stevenson extensively in his report (Navier, 1823). Navier translated material about UK bridges from Stevenson (see Figure 6). He also compared the rigidity of cable-stayed (Poyet system) with suspension bridges and the material required for the two, but did not write negative conclusions about the cable-stayed bridges. On page 210 of the Memoirs he states that his intention was to present

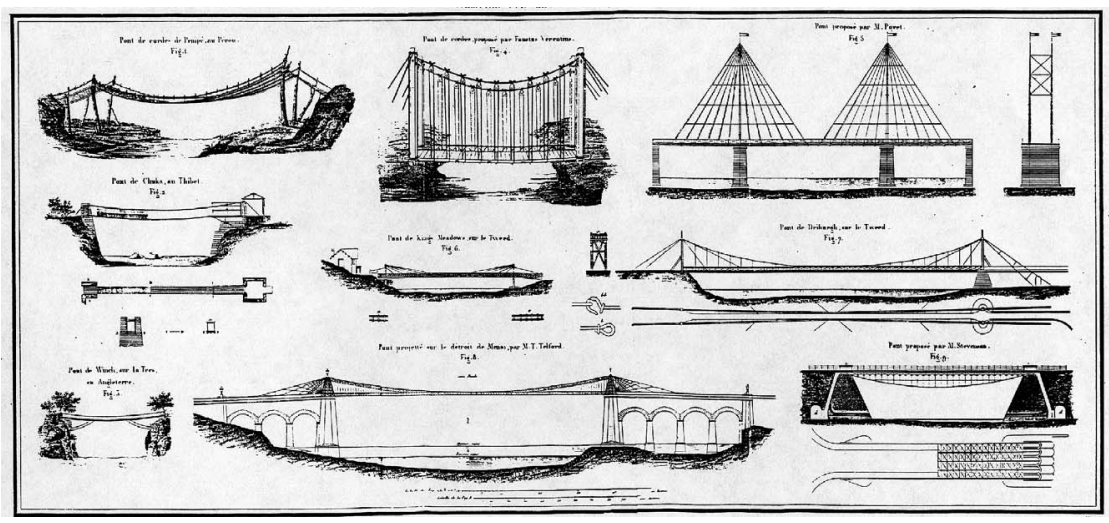

Figure 6. Plate from Navier (1823) 
facts and computations - not judgements (A. Bayrons, 1995, English translation of selected pages of Navier (1823), private communication). None of Poyet's designs was built, probably because of much controversy.

\section{Bandhauer's bridge design}

Figure 7 is an elevation view of the bridge based on Bandhauer (1827b, 1829). It comprised two, opposite-hand, single-tower cable-stayed bridges, capable of standing independently, which were connected at midspan by a double-leaf bascule. The bascule leaves could be lowered to permit the passage of sailing vessels without the need for unshipping masts. In that sense the bridge could be classified as a movable bridge. Bandhauer used the Kalenberger dimensional unit Fuss for his designs, which was equivalent to $29.33 \mathrm{~cm}$. The major dimensions of the bridge were (Bandhauer, 1829: p. 34)

overall length 404 Fuss $(118 \cdot 5 \mathrm{~m})$

span between tower centrelines 270 Fuss $(79 \cdot 2 \mathrm{~m})$

length of bascule leaf 5.2 Fuss $(1.5 \mathrm{~m})$

averall width of the roadway deck 26 Fuss $(7 \cdot 6 \mathrm{~m})$

- height of stay saddles (atop the towers) above stiffening girder 50.5 Fuss $(14.8 \mathrm{~m})$

distance from design waterline to top of stiffening girder (at tower) $13 \cdot 2$ Fuss $(3.9 \mathrm{~m})$

- design waterline was set at highest level of 1784 , which was $14 \cdot 25$ Fuss $(4 \cdot 18 \mathrm{~m})$ above normal high water.

The two towers were timber portal frames resting on the masonry piers as shown in Figure 8. The structural members were clad with wood and painted so as to give the appearance of building stone. A cast iron cable saddle rested atop each tower column for attachment of the stays and to transfer the vertical components of the stay forces to the timber columns.
Rather than use wire stays, as had been done for Kings Meadow, Bandhauer chose round wrought iron bars joined together from 4 to 5 -m-long pieces in a net-like pattern. Bridge stays (forestays) extended diagonally from cast iron saddles atop the towers to adjustable toothed connections at alternate floor beams. The eye ends of the stays were connected to the castings by pins stressed in double shear. Three backstays in each stay plane extended diagonally downwards from the tower casting through stone anchor blocks embedded in the bottoms of the anchorage walls.

The word 'cable' here designates a structural member that resists load mainly by direct tensile stress, any bending stresses being due to participation or imperfections. The cable may be a single wire, or a multiplicity of parallel wires, or a solid rod (circular cross-section) or bar or strip (rectangular crosssection). A cable may also be a strand, a multiplicity of wires helically wrapped around a wire, or could be a rope, which is a multiplicity of strands helically wrapped about a central strand or wire. The wire referred to was usually of metal, wrought iron or carbon steel.

Bandhauer's original design had articulated stay joints similar to those of Union Bridge shown in the lower left-hand corner of Figure 5. However, Bandhauer was concerned about joint instability due to possible reversals of bar forces between tension and compression, and that the joints would wear because the lightweight bridge would be susceptible to vibration. He changed the joint design to eliminate bolts. Instead of bolts he transferred force using ratchet teeth similar to the teeth of alligator clips (Birnstiel, 2005), as shown in Figure 9. The new detail also provided for connection of the circumferential stays.

The suspended structure comprised timber floor beams that supported longitudinal timber stringers for the roadway and sidewalk decking, stiffening girders, and lateral bracing (see

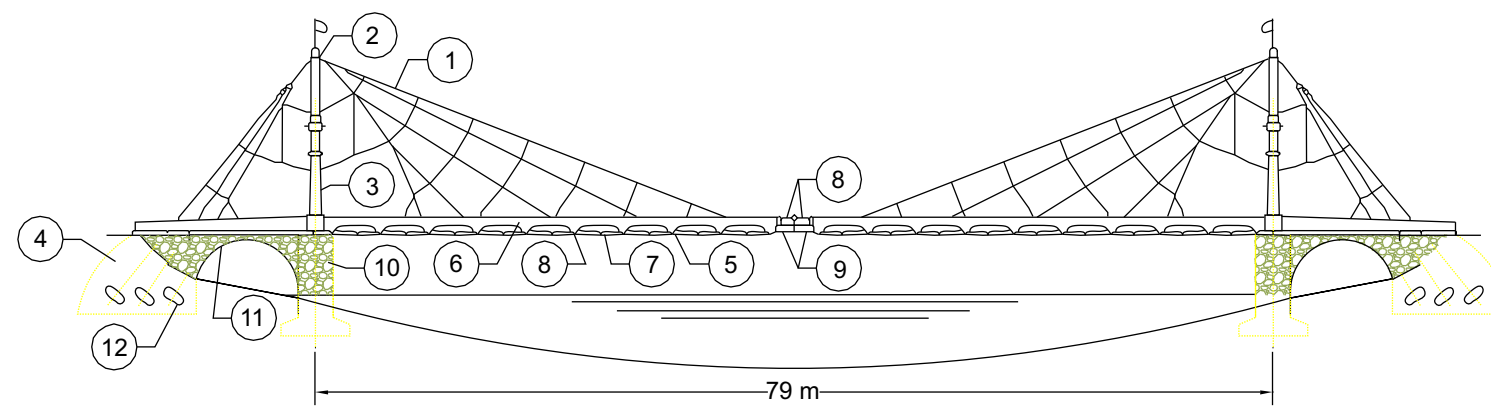

Figure 7. Elevation of the Nienburg Bridge: 1. wrought iron stays; 2. cast iron saddle; 3. Timber tower; 4. cable anchorage (wing wall); 5. timber floor beam; 6. timber stiffening girder; 7. timber lateral cross-bracing; 8. hinged girder panels; 9. deck leaves (fold downwards); 10. masonry pier; 11. masonry arch; 12. stone anchor block. Source: Courtesy Thomas Telford (Bridge Management 5) 
Engineering History and Heritage

Volume 166 Issue EH4
Collapse of a cable-stayed road

bridge in Germany in 1825

Birnstiel

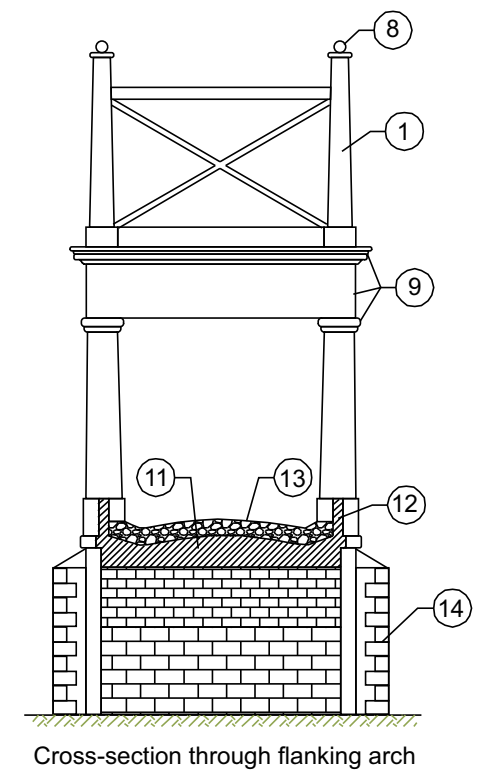

Figure 8. Cross-sections showing a bridge tower: 1. oak column; 2. stiffening girder; 3. portal truss; 4. bracing; 5 . iron band;

6. bolt; 7. upper tie beam; 8 . saddle; 9 . timber cladding; 10 . timber

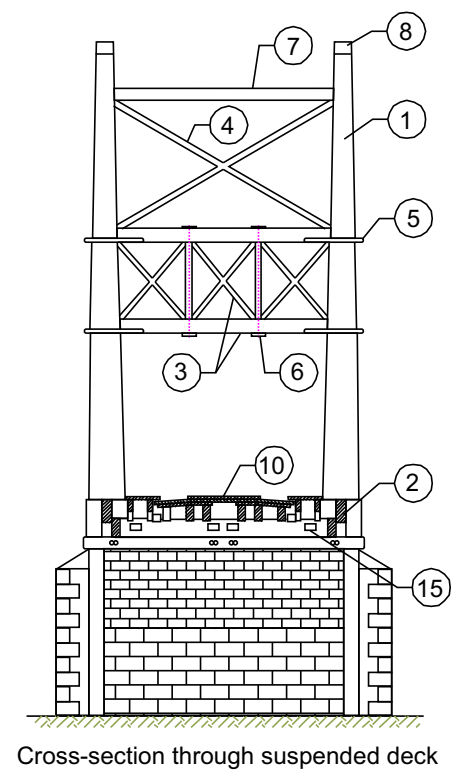

deck; 11. masonry arch; 12. masonry parapet; 13 . pavement and sub-base; 14. cutwater; 15. bottom laterals. Source: Courtesy Thomas Telford (Bridge Management 5)

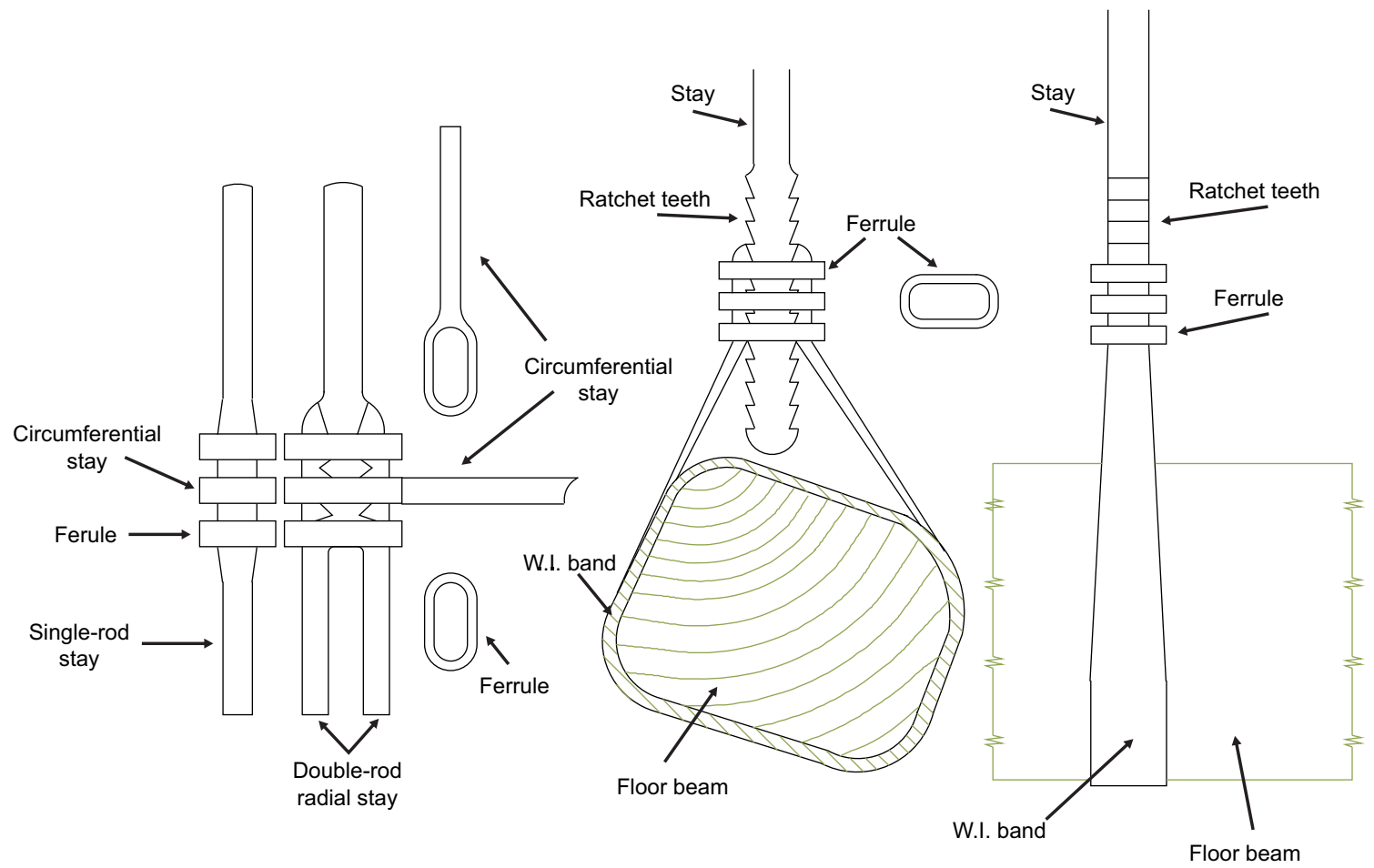

Figure 9. Stay connections. Wrought iron: W.I. Source: Based on Bandhauer (1829) 
Figure 10). A $2 \cdot 35 \mathrm{~m}$ wide carriageway for wagon traffic was flanked on each side by a walkway for animal tenders and $1.17 \mathrm{~m}$ wide sidewalk for pedestrians. The overall width of the deck was $7 \cdot 63 \mathrm{~m}$.

Details of the bascule leaves are shown in Figure 11, longitudinal cross-sections taken at the interior face of the barricade and through the bascule leaf. To open the leaves, bolts 9 were withdrawn from eyes 7 and the hinged leaves lowered in sequence by paying out chain from the chain drums. With the leaves lowered, the two trussed parts of the longitudinal barrier were unlatched and swung inward (with the release of more chain) thereby opening a passage for the ship masts. To close the bascule, the leaves were raised by means of two chain hoists and then locked into place by inserting bolts 9 into eyes 7 .

Bandhauer's design was based on a computed dead load of the suspended structure of 147670 Berliner Pfund (6919 kg). He assumed a live load of 1100 persons at an average weight of 165 Berliner Pfund $(77 \mathrm{~kg}$ ) uniformly distributed over the suspended bridge deck for a total live load of $85039 \mathrm{~kg}$ (Bandhauer, 1829: p. 43). For sizing the stays Bandhauer used a minimum factor of safety of 2 with respect to the assumed ultimate strength of the rods. He justified the factor of safety of 2 based on a statement in Eytelwein (1808: p. 264) and the need for stringent economy, and furthermore that loading by 1100 persons was unlikely except in wartime, which was not threatening.

\section{Bridge construction}

Shortly after the meeting of 10 January 1824 the Duke approved the project and the first stone was laid on 24 March.
A contract for manufacturing the wrought iron stays was let on 4 April with the stipulation that half of the stays be delivered by the end of June and the remainder by the end of July. Because of a design change to stay connections (described later) the ironwork contract was amended with delivery extended to 29 October. The first stays were satisfactory, but the quality steadily deteriorated in later shipments. Bandhauer had a machine built to proof test each wrought iron bar. Forty per cent of the delivered pieces failed the first test and had to be reworked at a forge located at Baasdorf, some $5 \mathrm{~h}$ distant from the bridge site (Bandhauer, 1829). After reworking, most bars passed the proof test but the need to rework so many bars seriously delayed the job and compromised the stays.

\subsection{Stay material}

The stays (cables) of the Nienburg Bridge were solid wrought iron rods of circular cross-section. Wrought iron (WI) is an ancient form of iron, a physical mixture of high-purity iron and fine glass-like slag fibres (Sim and Ridge, 2002). Slag (iron silicate) is normally considered unwanted waste material. An important aspect of wrought iron manufacture is the removal of some of the slag from the mixture, but not all. The iron and slag are in physical association, not in a chemical bond. It may be considered to be a low-carbon steel containing, usually, less than 3\% slag (Marin, 1952).

As the bridge was erected the lightweight construction became evident to the public. Although Bandhauer maintained his design was structurally adequate, he attempted to mollify critics by providing for doubling the number of stays and columns in the future - the next year - because the building costs had already reached 8000 Thaler, twice the original

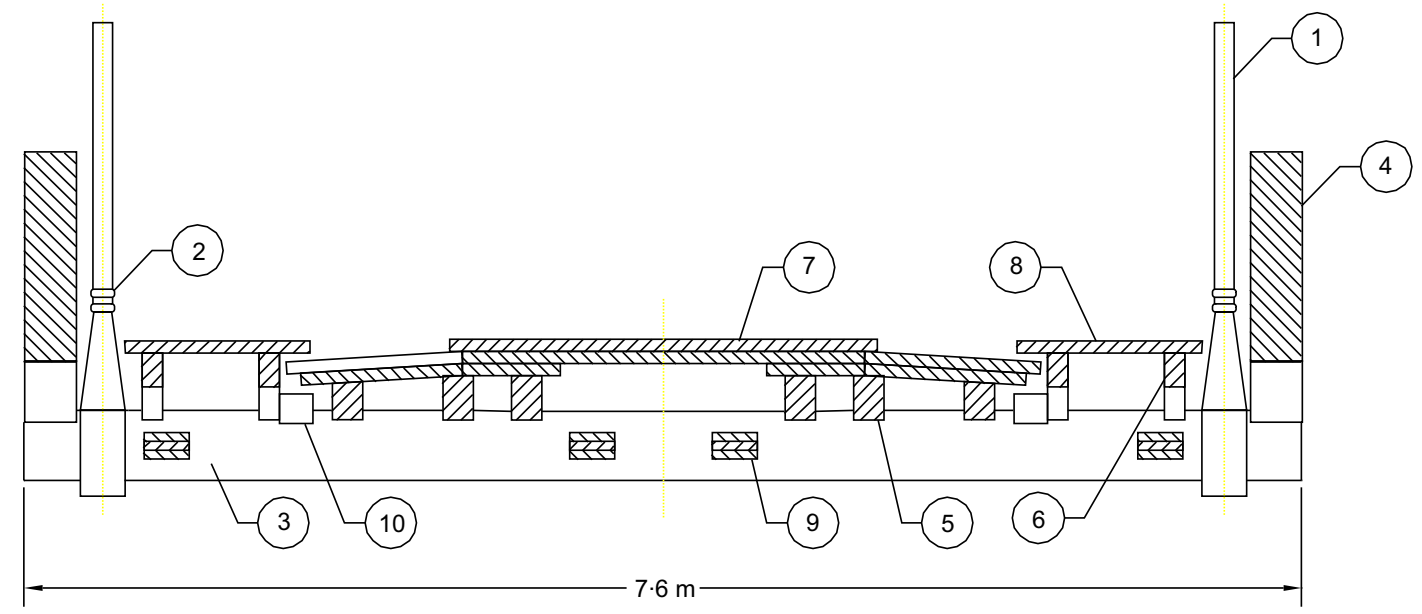

Figure 10. Cross-section through suspended deck: 1. wrought iron stays; 2 . locking sleeve; 3 . timber floor beam; 4 . timber stiffening girder; 5 . roadway stringer; 6 . sidewalk stringer; 7. roadway deck;
8. sidewalk deck; 9. lateral cross-bracing; 10. debris shield. Source: Courtesy E \& FN Spon (Bridge Management 3) 


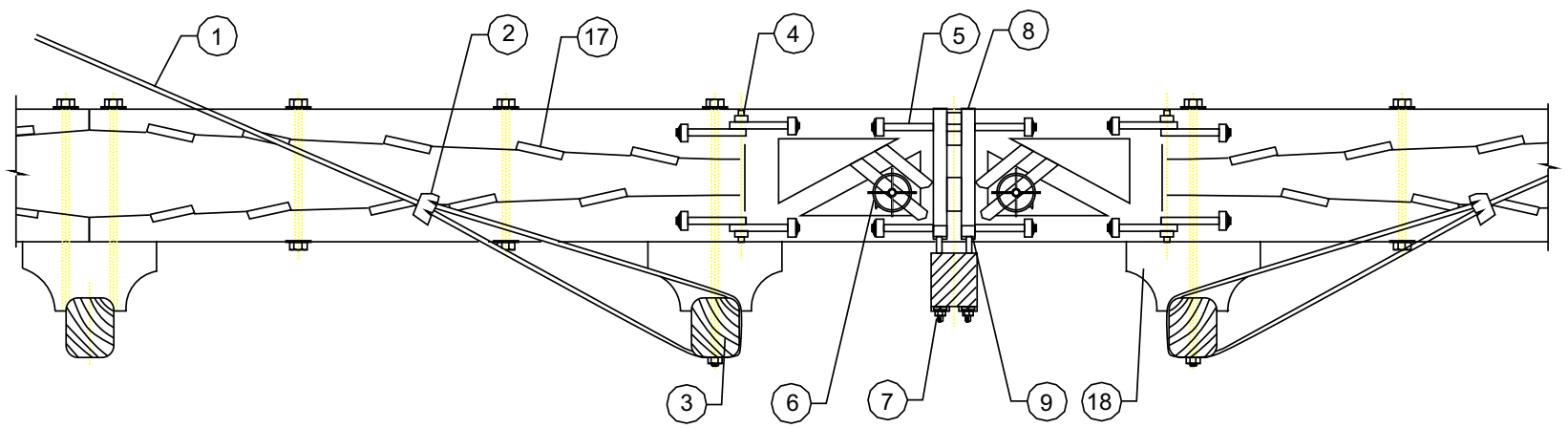

Cross-section at interior face of barrier

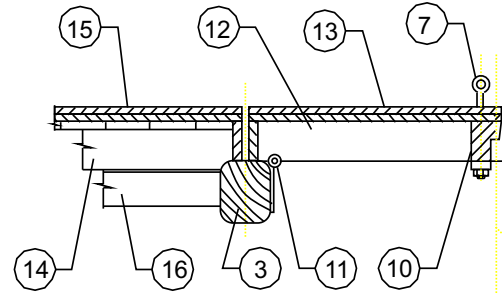

Deck leaf raised

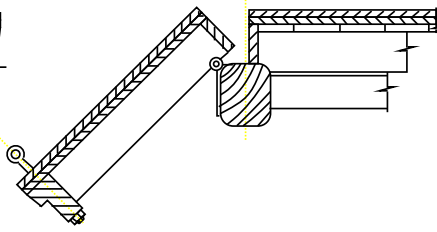

Deck leaf partially lowered

Cross-section through movable floor panels

Figure 11. Detail of double-leaf bascule: 1. wrought iron stays; 2. locking sleeve; 3. timber floor beam; 4. hinge; 5 . locking bar; 6. chain drum; 7. eye rod; 8 . wrought iron strap hanger; 9. bolt through hanger and eye rod; 10 . leaf floor beam; 11. leaf hinge;
12. leaf stringer; 13. leaf decking; 14. fixed deck stringer; 15. fixed deck; 16. lateral truss; 17. shear key; 18. Timber bolster. Source: Courtesy E \& FN Spon (Bridge Management 3) estimate. However, the bridge foundation was modified in January 1824, to accommodate the future reinforcements (Siebert, 1900: p. 9). Whether Bandhauer really thought the reinforcement was necessary or whether he proposed it in order to 'buy peace' will probably remain unknown.

\subsection{Bridge load tests}

After the bridge was nearly complete its lightness was more evident and became a matter of controversy. Bandhauer decided to counter the talk by conducting another load test. At 7 p.m. on 22 August 1825, he started a load test with two civic official witnesses. At the time the scaffolding was still in place under the span. The officials first verified that the bridge hung free of the scaffold. Then, at 8:45 p.m. a wagon loaded with $5154 \mathrm{~kg}$ of cut stones was hauled across the bridge by a ten-horse team. Bandhauer wrote that the total test load was $10 \mathrm{t}$ on a loaded length of $26 \mathrm{~m}$. The officials then again inspected the bottom of the deck and satisfied themselves that it was free of the scaffold. However, the public was not satisfied because the test was performed in moonlight, and requested that it be repeated. The retest was scheduled for the afternoon of 27 August. In the presence of many spectators, a wagon was pulled across the span three times at a fast clip, successively loaded with more cut stone. On the last run, the stone weighed $5956 \mathrm{~kg}$, giving a total load of $10.5 \mathrm{t}$. No unusual movements of the bridge were noticed while the wagon passed over the bridge and no permanent change in the shape of the bridge was evident. Bandhauer reported the test results to the Royal Administration in Cöthen, which set 6 September 1825 as the opening date for traffic.

\subsection{The bridge collapse}

The events leading to the torchlight procession of enthusiastic celebrants to the bridge, and Bandhauer's strenuous objection to the celebration, are summarised in Birnstiel (1996). At about 8:30 p.m. the procession led by Nagel, the initiator of the celebration, moved from the palace northwards to the bridge, halting at midspan where a table had been placed for the musicians. The torch bearers grouped near the musicians. Only a few persons continued past the bascule onto the northern half 
of the bridge. Nagel ordered the crowd on the southern half of the bridge to move to the east side so that they would not obstruct the music spreading towards the palace. Figure 2 shows the geographical relationship between the bridge and the palace. As a result of commanding the spectators to move to the east side of the bridge, the live loading on the bridge was unsymmetrical, both longitudinally and transversely. The inspector of mills, Wille, testified that he thought 200 people were congregated on the east side of the bridge, on the river side of the portal. Both Mahner and Wille commented on the water content of the bridge timbers as a result of the almost daily rain during the previoius month.

As the band played, 'Heil dir o Ferdinand' to the melody of 'Heil dir, im Siegerkranz' ('God save the King'), some youths tried to excite the bridge in time to the music. The narrative published by the court includes the statement that "versammelte Menge nach dem Tache der Musik die Brücke in eine schwingende Bewegung zu setzen gesucht haben' (Bandhauer, 1829: p. 254). Translated: the people tried to set the bridge into a swinging motion. It does not read that harmonic motion had actually occurred. A public official named Mahner testified that just after the first stanza ended, he heard a retort - like a pistol shot - looked at the stays, but did not see anything unusual. However, Siebert wrote in his conclusion that the southern half of the bridge was set into motion in time to the music. He wrote 'halbe Brücke gewaltsam nach dem Takte der Musik in schwingenden Bewegung versetzt' (Siebert, 1900: p. 18). Then it happened - the three southeast backstays (member numbers 213, 214 and 234 in Figure 12) parted. Shortly thereafter the southwest backstays fractured leaving the tower portal to resist the pull of all the forestays. Because the connections between the tower columns and the abutment could not resist much bending moment, the south tower portal toppled towards the river and the southern half of the bridge dropped into the water.

The number of dead and injured varies in different accounts of the disaster. The most reliable accounts may be those of Vogel (1986, 1989). Based on the records in the city archive, the

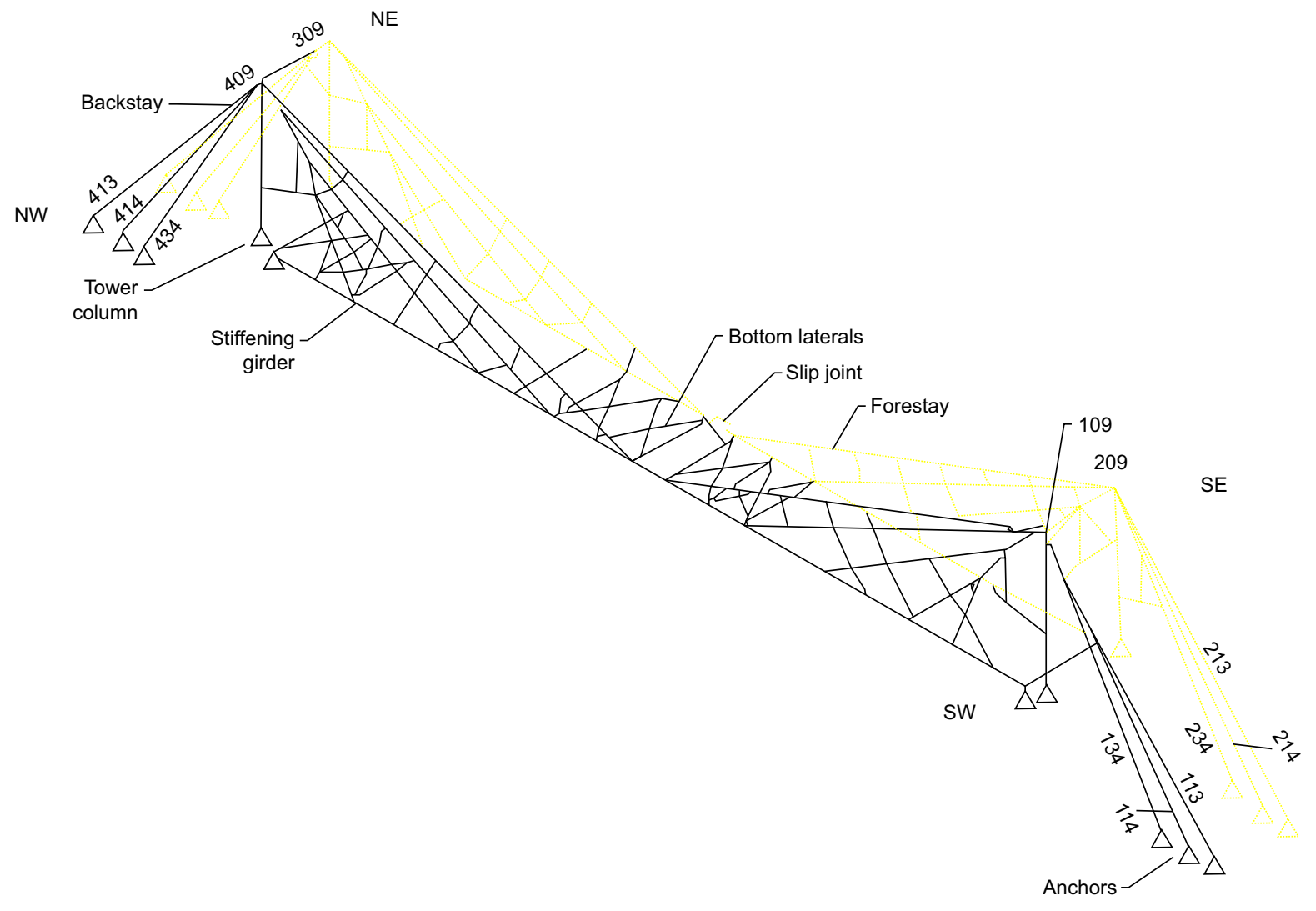

Figure 12. Simplified diagram of computer model. Notes: Not all components of bottom lateral bracing shown; not all components of east stay system shown; tower portal bracing not shown.

Source: Birnstiel 
Engineering History and Heritage

Volume 166 Issue EH4
Collapse of a cable-stayed road

bridge in Germany in 1825

Birnstiel church registers, and other sources, Vogel concluded that there were

282 persons on the whole bridge

30 persons on the north half of the bridge

252 persons on the south half of the bridge

- 186 adults and 66 children on the part that fell

55 persons died

60 persons were injured

two bodies remained missing.

The church records show only 49 dead. The discrepancy is probably due to the fact that Jews were not church members, and hence their deaths were not recorded in the church register. City records indicate that 25 Jews were in the torchlight parade, of whom four died.

\subsection{Collapse investigation}

Immediately after the disaster Duke Ferdinand dispatched a city official to Cöthen to inform Bandhauer of the bridge collapse, that people had died, and that he should come to Nienburg. Bandhauer went to Nienburg, viewed the wreckage, and asked for an official investigation because, translated, 'proper use of the bridge, without prior sabotage, could not have caused the disaster'. On 9 December the Duke asked three distinguished experts to review Bandhauer's technical work and write opinions: Oberlandesbaudirektor Eytelwein in Berlin, the Geheimer Oberbaurat Günter in Berlin and Oberbaurat Moller in Darmstatt, but all three men declined. Application was then made to the royal administration in Dresden, Saxony (another, larger, state in the German Confederation), who offered the services of Landesbaumeister Königsdörfer in Dresden and Machinendirektor Brandel in Freiberg, both of whom Duke Ferdinand accepted. Legal matters were to be investigated by Landkammerer von Behr and Kammerrat Bramigt from Cöthen. The Royal Great-British engineering and legal investigation began in the autumn of 1826 .

While the investigative commission was being organised provisions were made to secure the standing half of the bridge and the fallen debris in status quo. On 13 December 1825 the Hannoverian Landbau-Kondukteur C.G. Schuster examined the wreckage (Bandhauer, 1829: p. 113). He examined the fractures in the three southeast backstays and found them of different character, but mostly coarse grained at the middle of the bar cross-section and of finer grain near the edges. One fracture displayed a black band about a millimetre wide, which must have been caused by impregnation of the black oil-based paint that was probably applied at the forge before shipment to the building site. A second backstay fracture also displayed a wider black band. These black bands indicate that two of the three southeastern backstays had cracks before the bridge was erected. Overall, Schuster found seven fractures at which impregnation of black paint was clearly visible, indicating previous fractures. He found only one fibrous fracture. All would have been fibrous had the wrought iron been properly made. The defects in the form of fissures, non-uniform texture, porosity, and the presence of slag nodules indicate that there were problems at the manufactory and/or during the proof testing (Bandhauer, 1829: p. 114).

The public was enraged by the disaster and blamed Bandhauer for the collapse. He was accused of mistakes 'that the simplest carpenter would not have made'. Bandhauer was tried by a court comprising the legal faculty at the Royal Great BritishHannoverian Georg-August University at Göttingen. At the time of the collapse George IV of England also ruled the state of Hannover (which was one of the larger members of the German Confederation) (Newman, 1997). The three charges against Bandhauer are listed below.

The bridge concept was mainly his idea and had not been proved by experience.

- Mistakes occurred during construction, which he should have had corrected.

- He did not try hard enough to prevent overloading of the bridge on 6 December 1825 .

Bandhauer was absolved of these charges in May 1829. The court's reasoning was reprinted in Bandhauer (1829: pp. 273297) and it appears to the author to be a thorough and logical discourse.

\subsection{The Promemoria and Addendum}

After the bridge collapse an article prepared by officers of the Gewerbefleisses Verein in Preussen under the leadership of C. P. W. Beuth appeared containing an anonymous memorandum (Promemoria) dated 23 March 1825 by a Prussian Baumeister (master builder) (Beuth, 1826). He criticised Bandhauer's design claiming that the foundations were not adequately protected against scour, the masonry quality was poor, the wrought iron stays were too small, and the anchorages not heavy enough when the Saale River was at the flood stage. He reported that a trial load test had been conducted on one half of the bridge using a wagon loaded with $2.35 \mathrm{t}$ of stone. After the wagon advanced about $15 \mathrm{~m}$ onto the span some stays broke and the span dropped onto the scaffolding, which still remained from the erection scheme. The broken stays were repaired and reused.

The unknown Prussian Baumeister had doubts about the strength of the stay system. He claimed it to be 'obviously' too weak and commented on the severe vibrations that occurred under moving loads. He included computations to support the conclusion that the stay system was inadequate. He also wrote that Bandhauer had totally ignored lateral wind loads on the 
bridge, which is obviously incorrect because Bandhauer provided a horizontal truss below the deck to resist such forces.

Beuth (1826) includes an Addendum to the Promemoria, dated 25 February 1826, presumably by the same anonymous author. He described permanent displacements of the standing half of the bridge after the collapse. He claimed that the backstay fractures of the fallen half of the bridge did not exhibit defects (contradicting the observations of Schuster). He noted bridge deformations that had been observed before the collapse.

The bridge deflected about $25 \mathrm{~cm}$ under the passage of wagons.

- The floor beams visibly bent and twisted as loads passed over the bridge.

\subsection{Comments by Beuth}

According to C. P. W. Beuth, various Prussian officials had monitored the Nienburg Bridge construction (although they were foreigners) and had concluded that Bandhauer's bridge was a daring and unsafe enterprise. Furthermore, the Prussian building officials declared that this type of building should be discouraged. Beuth stated that the bridge, during the 3 months of use, had deflected $36 \mathrm{~cm}$ under dead load and at midspan was $18 \mathrm{~cm}$ under the horizontal line instead of $18 \mathrm{~cm}$ above it (18 $\mathrm{cm}$ design camber).

\subsection{Numerical collapse analysis}

After the author found the Promemoria and Addendum a decade ago, he decided that an attempt should be made to verify the large joint displacements of the stay net and compute the collapse load. Rasmin Kharva of Hardesty \& Hanover, LLC (NYC office) made static studies that suggested that there may have been approximately 285 persons, weighing an average of $70 \mathrm{~kg}$ on the span at collapse (Birnstiel, 2005). Subsequently, Bogdan Podgorniak of PSE Engineering Solutions, Inc. (Ontario, Canada) volunteered to make further structural analyses using the Robot computer program. All the static and dynamic numerical results listed here are thanks to Podgorniak.

An approximate numerical collapse analysis was made taking into account the non-linear effects of large displacements and inelastic material. Figure 12 shows the simplified three-dimensional model of the bridge superstructure (not all members are shown for clarity). It comprised 192 joints and 332 members. The member properties were based on the text and plates of Bandhauer (1827b, 1829). The node coordinates were based on dimensions scaled from an enlargement of a microfilm frame. The data were entered into the computer program Robot Millennium V18.0.1. That program is capable of analysing members having a bilinear stress-strain relationship. However, for the purpose of computing a collapse load of a structure so dependent on the tensile properties of wrought iron bars, especially the yield plateau, a more sophisticated stress-strain relationship was considered necessary. In effect, a tri-linear relationship was used by means of a manipulative device, but first, what value did Bandhauer use for the ultimate tensile strength of the stays?

\subsection{Bandhauer's mistake}

The linear units of measurement on Bandhauer's drawings were from the Kalenberger duodecimal system, which may be summarised as

$$
\begin{aligned}
& 1 \text { Fuss (foot) }\left(^{\prime}\right)=12 \text { Zoll (inch) }\left(^{\prime}\right. \text { ') } \\
& =144 \text { Linie (no equivalent) }\left(^{\prime \prime \prime}\right. \text { ) }
\end{aligned}
$$

The physical length of the Fuss varied between German states, and even within states, during the early 1800s. After the Congress of Vienna in 1816, the Prussian Fuss and the Cöthen Fuss were valued alike at $31 \cdot 385 \mathrm{~cm}$. However, despite the fact that Bandhauer made his design after 1816, he used the old Cöthen standard in his design, which was $130: 139 \cdot 13$ to the Prussian standard and 130:144 to the Paris standard (Bandhauer, 1829: p. 42).

Thus, Bandhauer's Fuss is given by

B. Fuss $=(130 / 139 \cdot 13)(31 \cdot 39)=29 \cdot 33 \mathrm{~cm}$

or

B. Fuss $=(130 / 144)(32 \cdot 48394)=29 \cdot 33 \mathrm{~cm}$

In which the Prussian and Paris standards are from Trapp (1992: pp. 223 and 226).

Bandhauer made a serious mistake in his assumption of the tensile strength of wrought iron bars. He took his value from a table on page 244, volume 2 of Eytelwein (1808), see Figure 13. That table was based on experiments reported in Musschenbroek (1762: p. 414). In Figure 13 the specimen material is listed in the first (left) column. The second gives the side dimension of the square cross-section in the Rheinland Zoll unit, and the fourth column gives the ultimate tensile strength in Berliner Pfund per square Rheinland Zoll. For good quality German forged iron it is 78035 and for common forged iron it is 71300 . Bandhauer used the average value of 74467 Pfund (Berlin) per square Rheinland Zoll. In order to convert that stress to modern metric units we note that a Berlin Handelspfund (Berliner Pfund) in the first half of the nineteenth century was equivalent to $468.536 \mathrm{~g}$ (Trapp, 1992: p. 231). A Rheinland Zoll would have been $(31 \cdot 385 / 12)=2 \cdot 6154 \mathrm{~cm}$ or $26 \cdot 154 \mathrm{~mm}$. The conversion from Berliner Pfund per square Rheinland Zoll to grams per square millimetre is 
Engineering History and Heritage

Volume 166 Issue EH4
Collapse of a cable-stayed road

bridge in Germany in 1825

Birnstiel

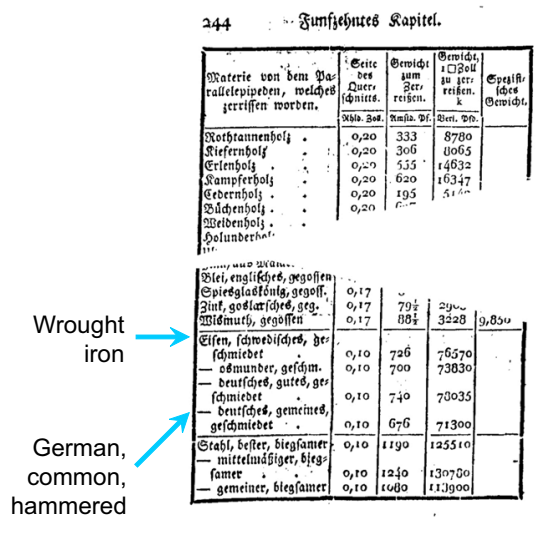

Figure 13. Ultimate tensile strengths of various materials (based on IMusschenbroek (1762) Introduction to Natural Philosophy).

Source: Eytelwein (1808)

$$
468 \cdot 536 /(26 \cdot 154 \times 26 \cdot 154)=0.6850 \mathrm{~g} / \mathrm{mm}^{2}
$$

Then the ultimate tensile strength of wrought iron assumed by Bandhauer was $(74467)(0 \cdot 6850)=51010 \mathrm{~g} / \mathrm{mm}^{2}$ or $51 \cdot 01 \mathrm{~kg} /$ $\mathrm{mm}^{2}$, which is equal to $51 \cdot 01(9 \cdot 8067)=500 \cdot 24 \mathrm{MPa}$, which is, in conventional USA units, $51 \cdot 01(1422 \cdot 334)=72553$ psi. His laboratory test specimens had been hammered down to a $2 \mathrm{~mm}$ square cross-section (Eytelwein, 1808). He probably used bars of such small cross-section because of the limitations of his experimental set-up. The second column of Figure 13 shows that he decreased bar size for stronger material. Bandhauer's stays were $24-48 \mathrm{~mm}$ in diameter, and hence their strength per unit area would only have been about $70 \%$ of the Musschenbroek specimens. Bandhauer apparently overlooked Eytelwein's emphasis on the size effect, which appears on page 249 of the same book; see Figure 14. The pertinent paragraph may be translated as

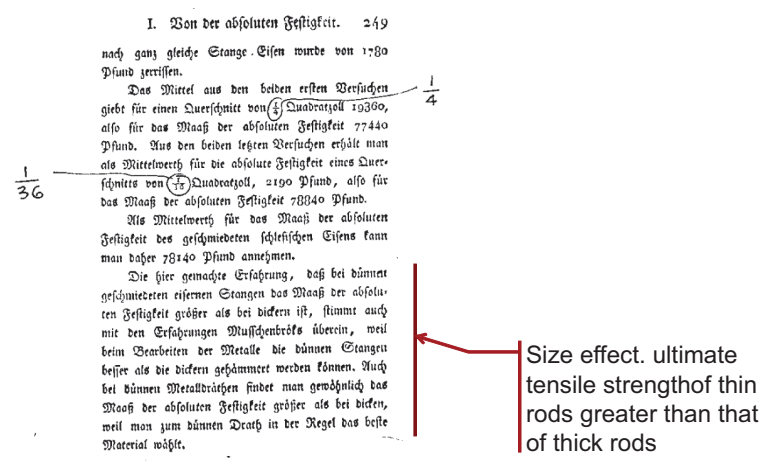

Figure 14. Size effect for wrought iron. Source: Eytelwein (1808)
The experience described above, that the ultimate strength of thin forged iron rods is greater than that of thicker rods agrees with the experience of Musschenbroek because during forging the thinner bars may be hammered more than the thicker bars. Also, the ultimate strength of thin wire is greater than that of thick wire because it is usual to select better material for the thinner.

Even with modern forging techniques there is a size effect for the physical properties of steel forgings. It is recognised in the ASTM standards, for example, ASTM A668/A668M.

\subsection{Stress-strain Input to computer program}

Despite an extensive literature search little information on a probable stress-strain curve for the wrought iron stays was found. As no stay material was available that could be sampled for testing, an artificial stress-strain curve was devised. The stress-strain curve shown in Figure 15 was developed from tensile test results given by the following reference sources.

Eytelwein (1808): Ultimate tensile strength of wrought iron of small cross-section from Musschenbroek tests shown on page 244, in units of Berliner Pfund per Rheinland Zoll. The values are: Swedish iron $=76570$; German good quality $=$ 78 035; German common $=71$ 300. On page 249 he emphasised that strength was less for bars of larger crosssections.

- Lamé (1826): The best wrought iron supported $26 \mathrm{t}$ per English square inch before tearing $(1 \mathrm{t}=1050 \mathrm{~kg})$.

Elongation started at two-thirds of that stress, and the elongation appeared to increase in geometric proportion as the load increased in arithmetic proportion. The worst quality iron broke at a stress of $14 \mathrm{t}$ per English square inch, it did not elongate.

- Trautwein (1874): Average ultimate tensile strength of wrought iron rolled bars
- ordinary $44800 \mathrm{psi}$
- good $60000 \mathrm{psi}$
v very superior $70000 \mathrm{psi}$
- best American 76100 psi
- English average 60000 psi.

Elastic limit approximately one half of breaking strength. Ultimate stretch from 5 to $30 \%$ of original length. Modulus of elasticity about 27000000 psi.

- Hütte (1899): Wrought iron in direction of fibres ('along the grain') proportional limit stress, $1300-1700 \mathrm{~kg} / \mathrm{cm}^{2}$. Elastic limit $2200-2800 \mathrm{~kg} / \mathrm{cm}^{2}$. Tensile strength 3300 $4000 \mathrm{~kg} / \mathrm{cm}^{2}$.

Johnson (1909): His Fig. 392 presents many stress-strain curves for wrought iron excerpted from Watertown Arsenal Report, dated 1890. Ultimate tensile stress 'along the grain' varies from 45000 to 55000 psi. Specimen size effect 


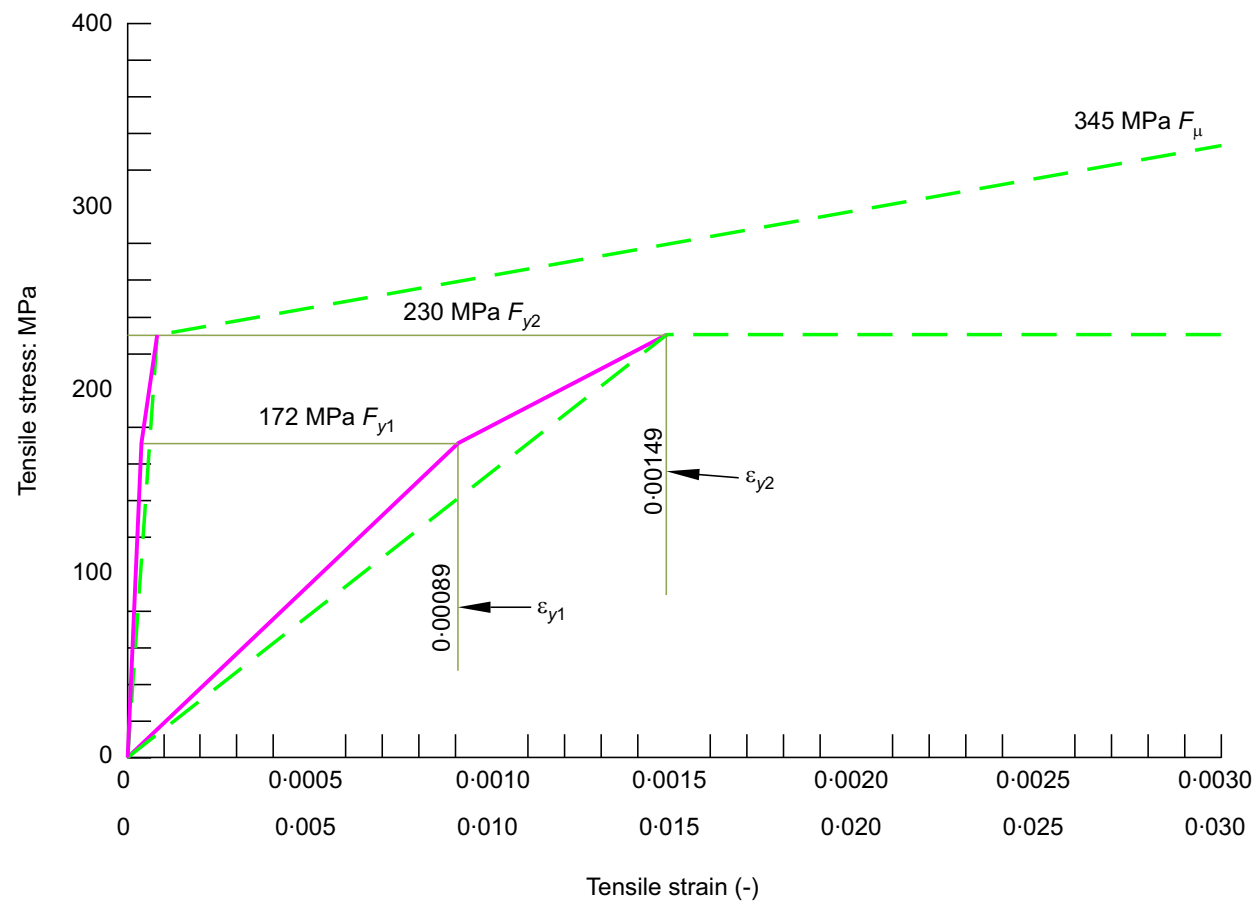

Figure 15. Artificial stress-strain curve used for structural analysis.

Source: Birnstiel

important. Elastic limit varies from 40000 psi in small rods to 23000 psi in 2-inch diameter rods.

- Burr (1915): Ultimate strength of wrought iron varies from 45000 to 50000 psi. Larger test bars showed lower strength. Modulus of elasticity $=26000,000$ psi.

Proportional limit $=26000$ psi.

- Seelye (1935): Wrought iron tensile strength $=60000$ psi Modulus of elasticity $=25000000$ psi. Proportional limit 30000 psi.

Marin (1952): Stress-strain curve characteristics.

An artificial stress-strain curve was used in the lower bound solution presented here (see Figure 15). The significant coordinates for this curve are

Lower knee $\mathrm{F}_{\mathrm{y} 1}=172 \mathrm{MPa}$, strain $=0.00089$

Upper knee $\mathrm{F}_{\mathrm{y} 2}=230 \mathrm{MPa}$, strain $=0.00149$

Ultimate $\mathrm{F}_{\mathrm{u}}=345 \mathrm{MPa}$, strain $=0.30000$

\subsection{Transverse and longitudinal load distribution}

The live load distribution used in the analysis is shown in Figure 16. For the lower bound solution (the only one reported here) the live load factor $Q$ was placed off-centre transversely, nearer to the easterly stays in order to simulate the location of the spectators at collapse (see Nagel's order for people to move to the east side of the bridge). The longitudinal distribution of live load factor $Q$ shown was selected to simulate the reported condition that few spectators were on the north half of the bridge at collapse.

\subsection{Structural analysis}

Because the version of Robot Millennium used in the analysis was only capable of utilising conventional bi-linear stressstrain curves two models were created to represent the artificial tri-linear stress-strain curve of Figure 15. In the first model only the first two sectors of the tri-linear relationship were considered in the region where the computed stress was less, or at most equal to, $F_{y 2}$. The second model was used to study the behaviour along the third segment of the tri-linear stressstrain curve, after stress $F_{y 2}$ was achieved in the most severely stressed element. The two bi-linear models are shown in Figure 15.

\subsection{Static analysis}

The live load factor $Q$ was monotonically increased and the structural displacements calculated at each load level. The analysis was continued to the point of non-convergence, which represented a vertical displacement at mid-span of about $500 \mathrm{~cm}$ at a live load factor of $Q=12 \cdot 5$ (see Figure 17). 


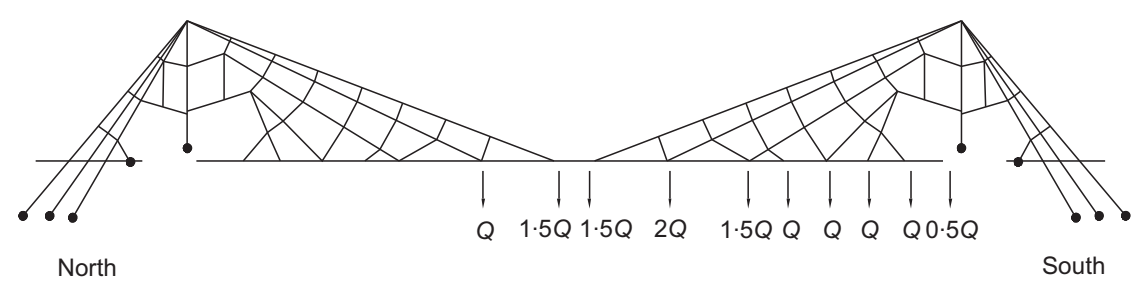

Total live load on bridge $=12 Q$

Longitudinal distribution
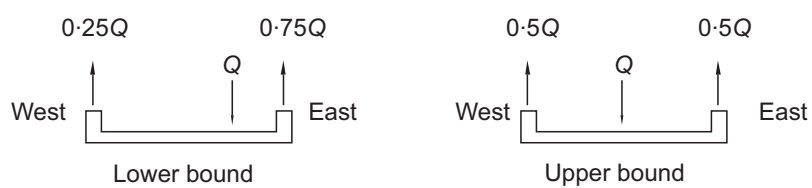

Transverse distribution

Figure 16. Assumed distributions of live load on bridge for structural analyses. Source: Birnstiel

Figure 18 shows the calculated horizontal displacement of the top of the southeast and southwest tower columns. It shows that the southeast column top started to move at about one half of the collapse load.
The displaced shapes of the easterly and westerly cable planes at the live load factor of $Q=12 \cdot 5 \mathrm{kN}$ are shown in Figure 19 . It indicates that the south bridge was leading the downward motion.

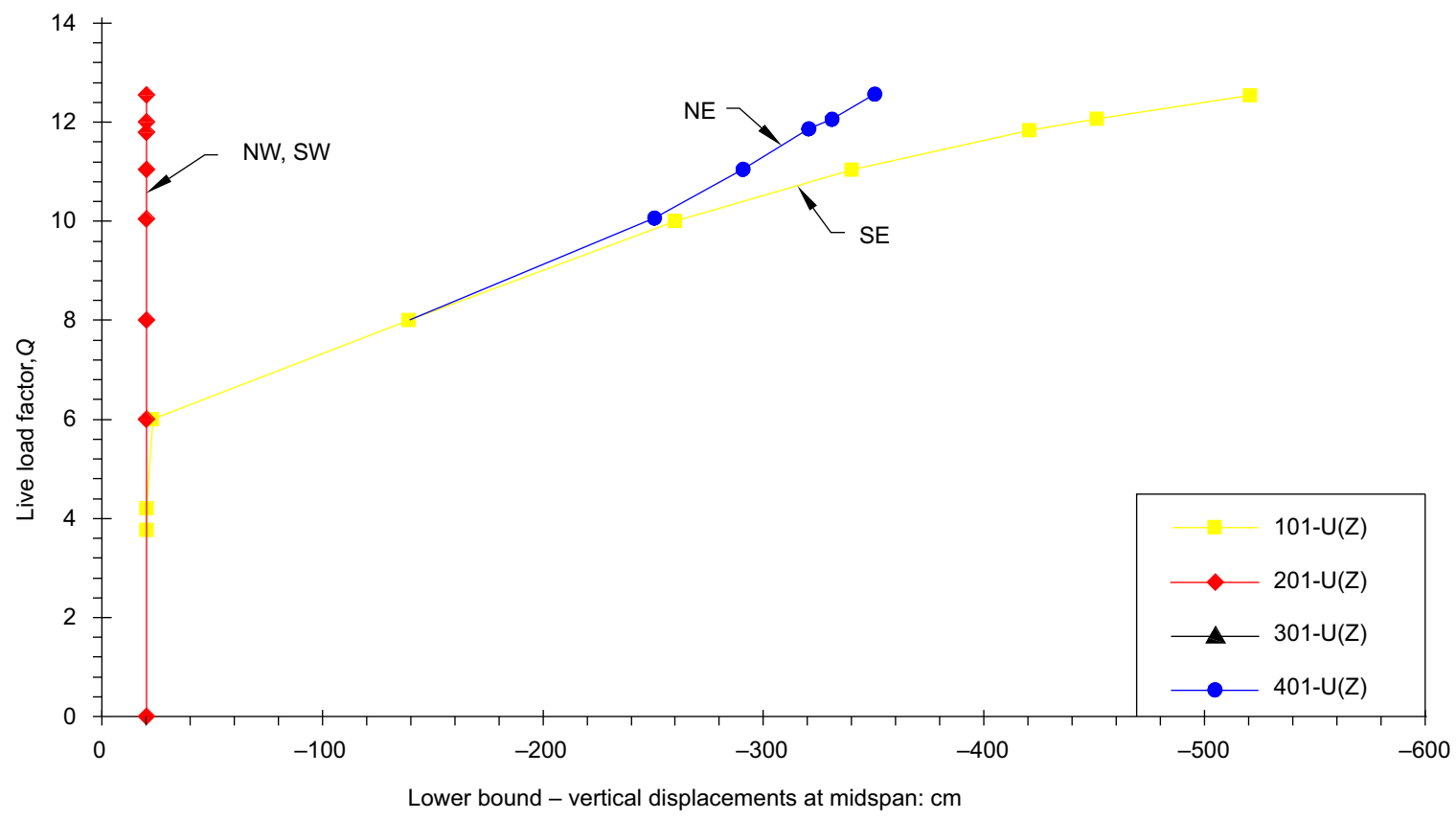

Figure 17. Vertical displacements at midspan. Source: Birnstiel 


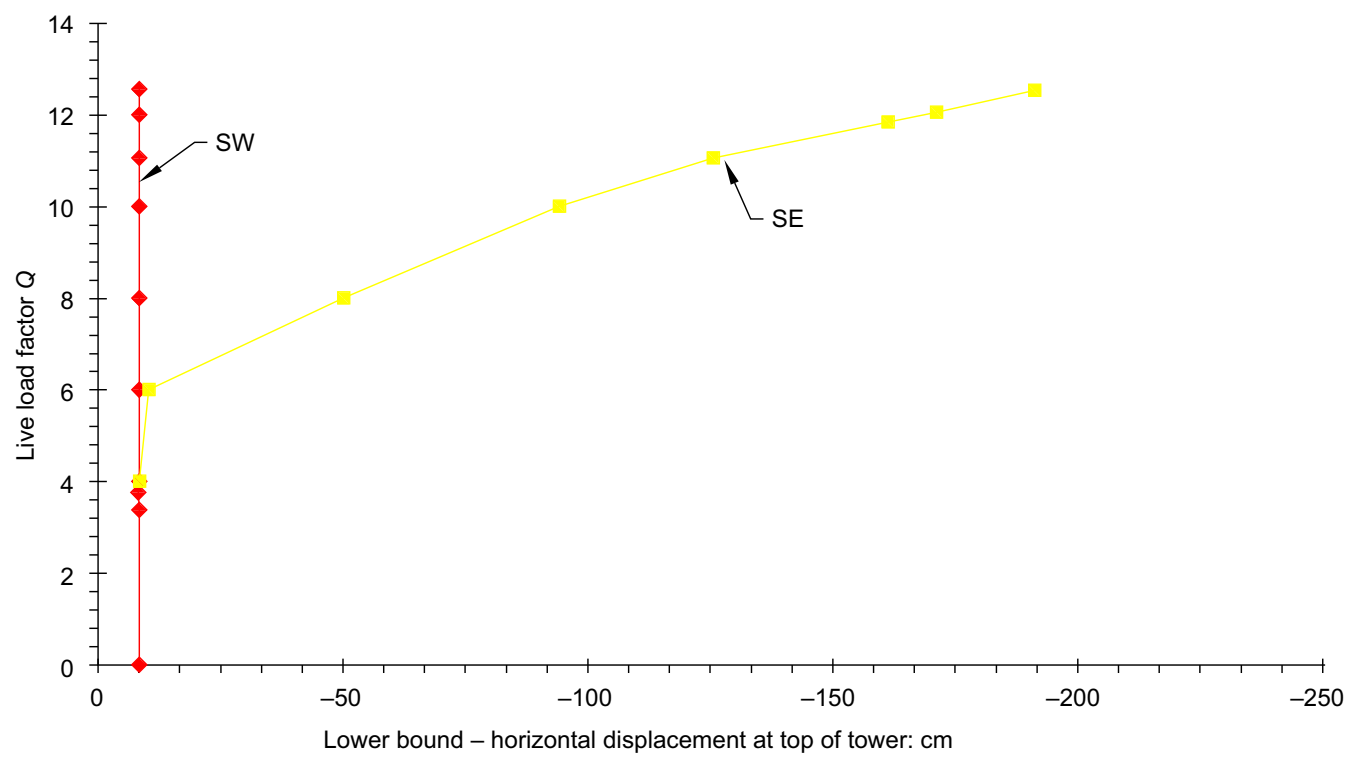

Figure 18. Longitudinal displacements (horizontal) of tower tops.

Source: Birnstiel

Figure 20 shows the variation in bar unit stresses with increased $Q$. There was much redistribution of stress in the stay network as $Q$ increased. Bar 213 (at southeast) was stressed to about $255 \mathrm{MPa}$, bars 214 and 234 to about $235 \mathrm{MPa}$. The corresponding bars at the southwest 113, 114 and 134 were stressed less. This is consistent with the observed mode of failure.

The value of the live load factor $Q=12.5 \mathrm{kN}$ represents about 255 persons weighing an average of $60 \mathrm{~kg}$. Vogel gives the total number of persons on the whole bridge at collapse as 282 (Vogel, 1989).

\subsection{Dynamic study}

In section 5 of the 'Zweifels - und Entscheidungs - Gründe' (evidence and basis of decision) the court wrote that the people on the bridge tried to set the bridge into vibrating motion, 'die Brücke in eine schwingende Bewegung zu setzen gesucht haben'. It did not say that it had been sent into harmonic motion. In fact, it states that the backstays ruptured just at the end of the first stanza of 'God save the King' (Bandhauer, 1829: p. 254). As the first stanza is only about $45 \mathrm{~s}$ long it is doubtful if the bridge could have been set into resonance during that time, considering damping in the system. The suspended deck and flexural stiffening system

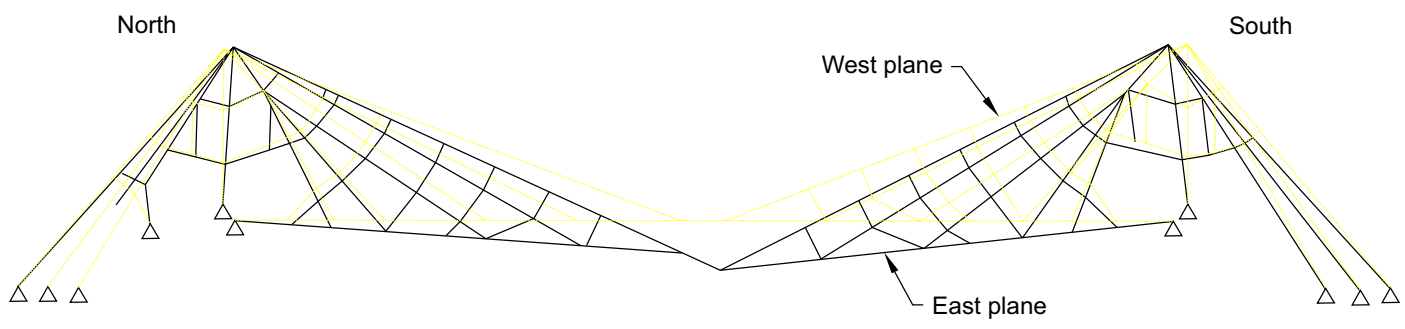

Cable planes at $Q=12 \cdot 5 \mathrm{kN}$

Figure 19. Deformed shape of cable planes at $Q=12.5 \mathrm{kN}$.

Source: Birnstiel 


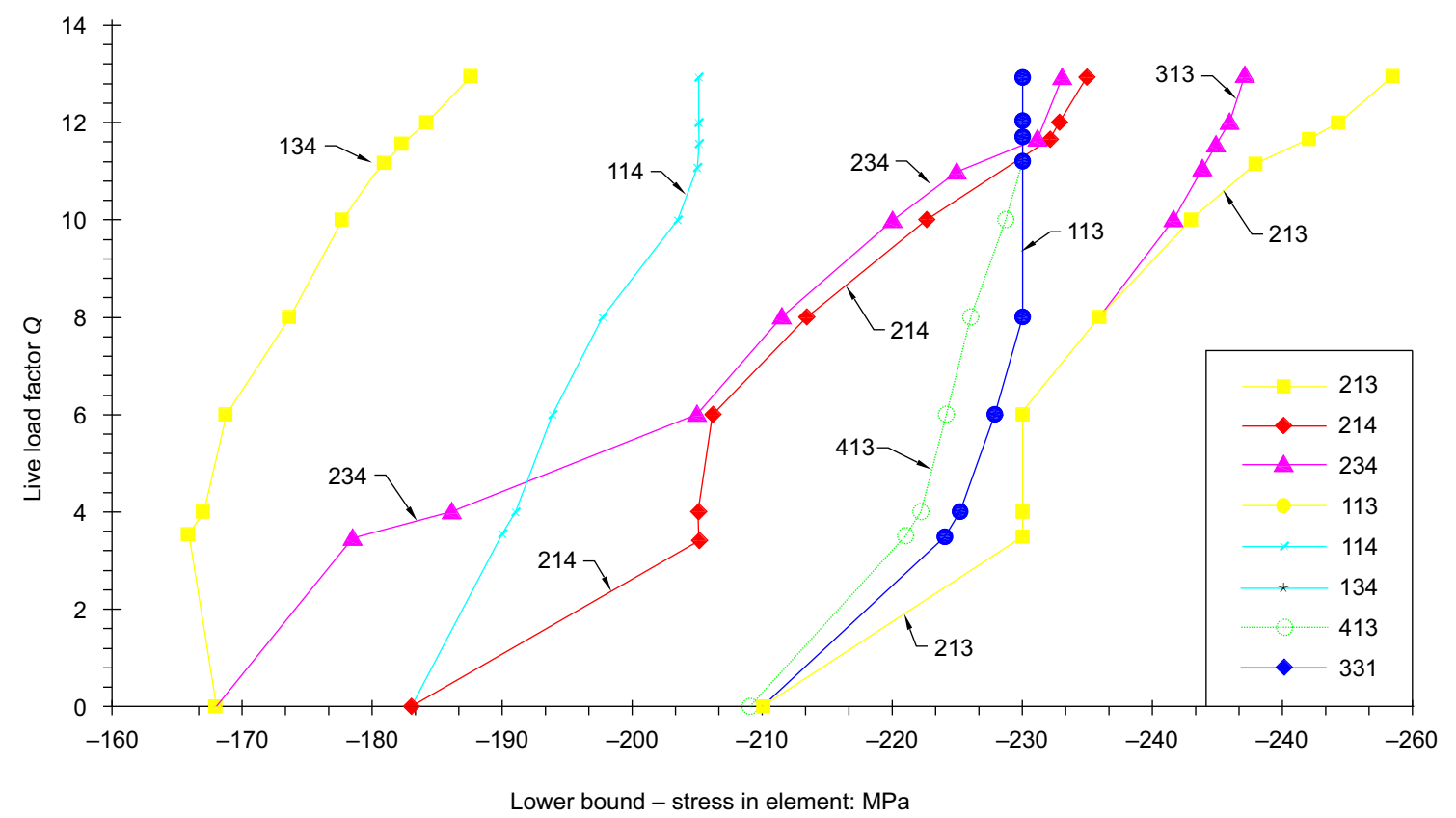

Figure 20. Unit tensile stresses in selected stays. Source: Birnstiel

were all of timber with many opportunities for friction at the many joints.

The speed at which the band played the song is of course unknown, but based on performances heard over the internet the period between vertical impulses by the youths may have been from 1 to $3 \mathrm{~s}$. It would depend on whether they jumped at every music beat or on alternate beats. The corresponding impulse frequencies would vary between $0 \cdot 3$ and $1 \cdot 0$ pulses/s. In order for the excitation to have significant influence on the stay stresses, a natural frequency of bridge vibration would have to be within that range.

Four linear elastic dynamic analyses for the natural frequency were made on the model of Nienburg used for the static analyses, for various ratios of live to dead load. The results for two cases are as follows.

\subsubsection{Case I: dead load only}

It was assumed that the structure was essentially elastic. The modulus of elasticity, $E$, for the stays was taken as that of the first part of the stress-strain curve shown in Figure 15; $E=$ $193258 \mathrm{MPa}$. The first three computed natural frequencies were: $1 \cdot 19,1.21$ and $1.75 \mathrm{~Hz}$. The mode of the lowest natural frequency, $1 \cdot 19 \mathrm{~Hz}$, was torsional (see Figure 21). The second natural frequency $(1 \cdot 21 \mathrm{~Hz})$ had a strong vertical component.

\subsubsection{Case II: dead load plus 75\% live load}

The live load of the 282 persons on the bridge at collapse was taken at $60 \mathrm{~kg}$ each, for a total force of $166 \mathrm{kN}$. Seventy-five per cent of this vertical force, or $124.5 \mathrm{kN}$, was distributed non-uniformly over the bridge as shown in Figure 16. Because
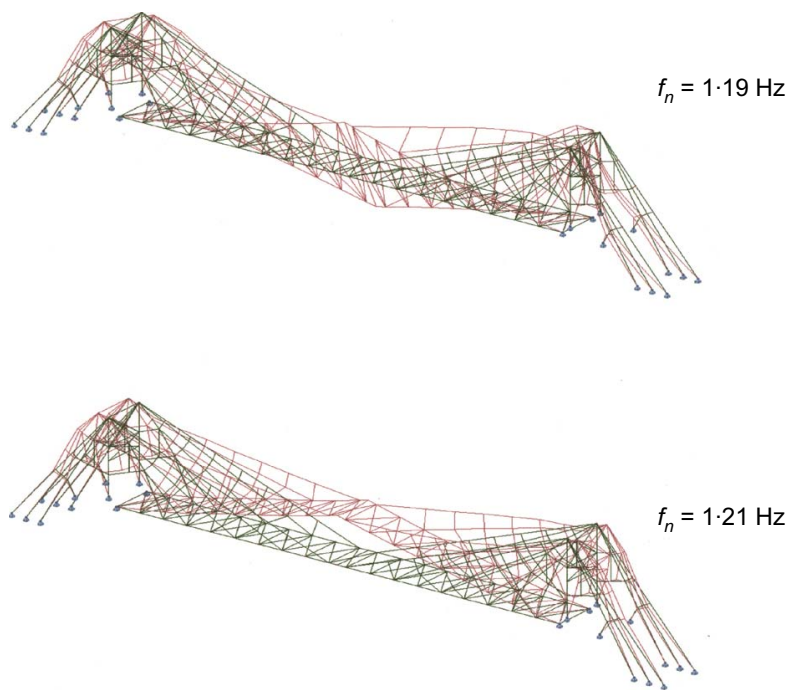

Figure 21. First two mode shapes of natural vibration under dead load only 
the stress in some bars exceeded the proportional limit under this live load the value of $E$ was taken as $154362 \mathrm{MPa}$ (the average of the first two segments or the stress-strain curve). The first three natural frequencies were $0.98,1.05$ and $1.50 \mathrm{~Hz}$. The modes for the first two natural frequencies, $0.98 \mathrm{~Hz}$ and $1.05 \mathrm{~Hz}$, are torsional and are depicted in Figure 22.

The results from the dynamic analyses for case I and case II indicate that resonance could have occurred before collapse because the lowest natural frequency of the bridge could have been close to the forcing frequency. If resonance did occur, the vibration would have increased stresses in the stays over the static stresses. The author is of the opinion that there are too many uncertainties about site conditions to warrant a more sophisticated dynamic analysis.

\section{Summary and conclusion}

In the years 1824-1825 a notable cable-stayed bridge was constructed across the Saale River at the city of Nienburg, in the present Land (state) of Anhalt-Sachsen, Germany. It was probably the first cable-stayed bridge with a fan-type arrangement of multiple fore- and backstays. The stay system also had orthogonal members, the totality forming a net when viewed in elevation. At the time, the bridge had the longest span and widest deck of any pure cable-stayed bridge and also the unusual feature of a double-leaf bascule at midspan. The bridge comprised two independent, single tower, unsymmetrical cable-stayed bridges with a double-leaf bascule between them. Unfortunately, the bridge was also notable for its short life of 3 months when the southern half of the bridge collapsed under a crowd of celebrants with the loss of 55 lives on 6 December 1825 .
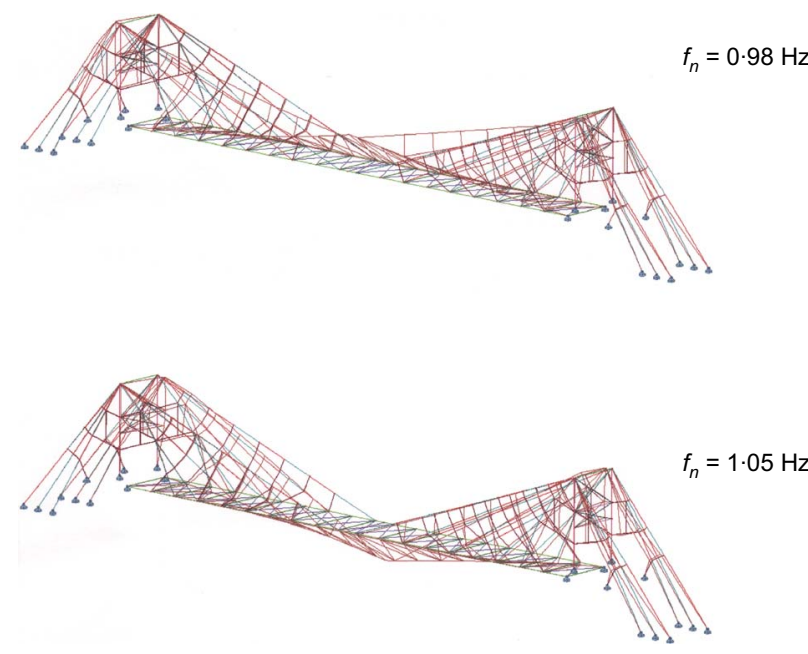

Figure 22. First two mode shapes of natural vibration under dead load plus $75 \%$ of live load
The author has not seen the report of a technical commission that investigated the disaster, but information about the bridge and its collapse was published by the bridge designer Christian Gottfried Heinrich Bandhauer in 1827 and 1829 and microfilm was made available to him. It is unlikely that a single cause for the failure can be isolated. The structural design had questionable details for the timber framing and the design of the stay system was light, by present standards, but those 'defects' would have affected the required maintenance over time, but not necessarily been the cause of a sudden collapse. A post-collapse investigation of the stay fractures showed defects in the wrought iron caused by improper smelting of the iron ore and pre-collapse defects in the stays due to improper forging of that wrought iron. However, the bridge had survived at least one heavy load test and a battalion of soldiers had crossed the bridge in formation before the collapse. So while the structural design may have been too light, the weight of the 283 persons, as such, was not likely to have caused the collapse, it was the distribution of that load and, perhaps, its dynamic character. That situation cannot be ascribed to Bandhauer, for he had strongly opposed the celebration. It seems more properly to have been due to inadequate policing of the spectators. However, Bandhauer could be criticised for the following.

- In his early presentations to the community he quoted an estimated construction cost that was far too low. By this action he may have sold the bridge, but it later limited his options on all other aspects of the project. This is not to say he intentionally misled Duke Ferdinand and the public, but in his enthusiasm he overlooked difficulties.

- Quality control at the smelter that produced the wrought iron stays was inadequate and may also have been inadequate at the forge which reworked the stays that had failed the proof tests.

- He underestimated the required construction time. He assumed the building could be completed in one season, from April to November 1824. He did not realise the effect of the autumn storms and the spring flooding of the Saale River on building.

- He appears to have been obsessed with the need for economy. This mentality may have contributed to his disregard of the size effect on the tensile strength of wrought iron and the use of a factor of safety with respect to strength equal to 2 when sizing the stays.

- Although he objected strenuously to the celebration, he probably should have called attention to the need for crowd control because he was aware of the vibrations of the British cable-supported bridges from Stevenson (1822).

- He overestimated the skills of the local workers. The Nienburg area had been devastated during the Napoleonic Wars and the required talent was no longer available.

- He did not have adequate management back-up. Bandhauer was in complete charge of the project, from conception to 
execution (as was the fashion at the time), but his office and dwelling were in Coethen, many hours distant from the bridge site and he could not perform the necessary quality control at the ironworks and at the bridge.

Bandhauer was acquitted of all charges in a judicial proceeding by the law faculty of the Royal Great British-Hannoverian Georg-August University at Göttingen, Germany.

An approximate non-linear numerical collapse analysis was made using a three-dimensional computer model, which took into account large joint displacements and inelastic material behaviour. The numerical results confirmed the flexibility of the structure and the collapse mode. The computed number of persons on the bridge at collapse agrees reasonably well with the published numbers that were based on records compiled shortly after the collapse. An appropriate vibration analysis was made. The results indicate the possibility of resonance when spectators tried (or did) excite the bridge in time to the melody of 'God save the King'.

Lessons that civil engineers could and should have learned from the Nienburg collapse include the following.

When proposing a construction project provide a realistic estimate of the construction cost and the time required to perform the work.

- Engineers should use reliable climatic data and local knowledge of rivers.

- When part of a project involves an advance in technology, or technology transfer from another discipline, design that aspect conservatively and allow extra funds and time to do that work

- Insist that there be adequate provisions for quality control at the suppliers, fabrication shops and at the assembly site.

- Document all design changes, disbursements and the progress of the work in anticipation of post-construction criticism.

\section{Acknowledgements}

Many individuals provided information and assistance during this study of the Nienburg Bridge collapse. Foremost among them was the late Dr Erich Vogel, a local historian in Nienburg-an-der-Saale, who cheerfully supplied copies of paintings and publications related to the event. Frau Claudia Lucke, a librarian at the Nienburg Stadtsbibliotek, also provided documents and old photographs.

Libraries that were consulted included: the Sächische Landesbibliotek, Dresden; the Archives of the Institution of Civil Engineers in London (Mike Chrimes and Carol Morgan); Universitaets Bibliothek, Technische Universiitaet, Dresden; the Queensborough Library in New York City (Margaret Birnstiel); the collection of the former Engineering Societies
Library in New York City (now at the Linda Hall Library in Kansas City, Missouri); the Engineering Library of New York University (until 1973); the Science, Industry and Business Library in New York City; the Columbia University Libraries in New York City; the Stadtsarchiv Köthen/Anhalt (Frau Knof); Landesarchiv Oranienbaum (Dr Hoerolt); and the Museum Schloss Bernberg (Dr Juergren Weigelt).

Additional data and help were furnished by Frau Gisela Wordell of the Fraunhofer Informationszentrum, Reinhart Birnstiel, William X.F. Bowden, Dr Karl Rabolt, Anton F. Steffan and Dr Henning Wilmers.

Bogdan Podgorniak of PSE Engineering Solutions, Inc. (Ontario, Canada) and Rasmin Kharva of Hardesty and Hanover, LLC (New York City) made forensic computer static structural analyses of the bridge based on the data published by the design engineer, Christian Heinrich Gottfried Bandhauer. The numerical dynamic studies were made by Bogdan Podgorniak.

\section{REFERENCES}

ASTM (2013) A668 / A668M - m13e1: Standard Specification for Steel Forgings, Carbon and Alloy, for General Industrial Use. ASTM International, West Conshohocken, PA, USA.

Bandhauer G (1827a) Verhandlungen über die artistische Untersuchung des Baues der Hängebrücke über die Saale bei Mönchen-Nienburg. C.H.F. Hartman, Leipzig, Germany.

Bandhauer G (1827a) Verhandlungen über die artistische Untersuchung des Baues der Hängebrücke über die Saale bei Mönchen-Nienburg. C.H.F. Hartman, Leipzig, Germany.

Bandhauer G (1827b) Kupfertafeln und Ihre Erläuterung zu den Schriften der Artistische Untersuchung des Baues der Hängebrücke über die Saale bei Mönchen-Nienburg. C.H.F. Hartman, Leipzig, Germany.

Bandhauer G (1829) Verhandlungen über die artistische Untersuchung des Baues der Hängebrücke über die Saale bei Mönchen-Nienburg. C.H.F. Hartman, Leipzig, Germany.

Bender C (1868) Historical sketch of the successive improvements in suspension bridges to the present time. Transactions of the American Society of Civil Engineers 5: 27-34.

Berg CFW (1824) Der Bau der Hängebrücken aus Eisendraht. Im Industrie-Comptoir, Leipzig, Germany.

Beuth CPW (1826) Ueber die Nienburger Kettenbrücke, etc. In Verhandlungen des Vereins zur Beförderung des Gewerbefleisses in Preussen, U. Petch, Berlin, Germany. vol. 5, pp. 65-92.

Birnstiel C (1996) On the collapse of a cable-stayed bridge at Nienburg: a nineteenth century disaster revisited. In Bridge Management 3 (Harding JE, Parke GAR and Ryall MJ (eds)). E \& FN Spon, London, UK.

Birnstiel C (2005) The Nienburg cable-stayed bridge collapse: an analysis eighteen decades later. In Bridge Management 5 
(Parke GAR and Disney P (eds)). Thomas Telford, London, UK.

Burr WH (1915) Materials of Engineering, 7th edn. Wiley, New York, USA.

Chrimes M (1985) Bridges: a Bibliography of Articles Published in Scentific Periodicals 1800-1829. In History of Technology, 10th annual vol. (Smith N (ed.)). Mansell Publishing Ltd, London, UK.

Drewry CS (1832) Memoir on Suspension Bridges. Longman, London, UK.

Droysens G (1886) Allgemeiner Historischer Handatlas. Verlag von Velhagen \& Klasing, Bielefeld and Leipzig, Germany.

Eytelwein JA (1808) Handbuch der Statik Fester Körper.

Realschulbuchhandlung, Berlin, Germany, in 3 vols.

Hütte (1899) Des Ingenieurs Taschenbuch, 175th edn. Ernst \& Sohn, Berlin, Germany.

Johnson JB (1909) The Materials of Construction. John Wiley, New York, USA.

Kurrer KE (2008) The History of the Theory of Structures. Ernst \& Sohn, Berlin, Germany.

Lamé (1826) Ueber die kettenbrücken und die Festigkeit des bei ihrem Bau angewendeten Eisens. In Verhandlungen des Vereins zur Beförderung des Gewerbfleisses in Preussen, Berlin. Translated extract of a letter by Lamé (Ingenieur des mines de France) to M. Baillet.

Lee R (2011) Relative backwardness and long-run development: economic, demographic and social changes. In 19th Century Germany (Breuilly J (ed.)). Edward Arnold, London, UK.

Leonhardt F and Zellner W (1970) Cable-Stayed Bridges: Report on Latest Developments. Proceedings of the Canadian Structural Engineering Conference. Canadian Steel Construction Council, Canada.

Leupold J (1736) Theatrum Pontificiale: Oder Schau-Platz der Brücken und Brücken-Baues. Christoph Zunkel, Leipzig, Germany.

Marin J (1952) Engineering Materials: Their Mechanical Properties and Applications. Prentice Hall, Englewood Cliffs, NJ, USA.

Musschenbroek (1762) Introductio ad philosophian naturalem. Ludg, p. 414.

Navier CLMH (1823) Memoirs sur les Ponts Suspendus. De L'imprimerie Royale, Paris, France.

Nestler E (1996) Bandhauer 1790-1837: Ein Klassizist in Anhalt. MICADO Verlag, Köthen, Germany.

Newman G (1997) Britain in the Hanoverian Age 1714-1837. Garland Publishing, New York, USA.

Parsons WB (1939) Engineers and Engineering in the Renaissance. Williams \& Wilkins, Baltimore, USA.

Ruddock T (1999) Blacksmith bridges in Scotland and Ireland 1816-1834. Proceedings of an International Conference on Historic Bridges to Celebrate 150th Anniversary of the Wheeling Suspension Bridge, Wheeling, Morgantown, West Virginia. West Virginia University Press, WV, USA.
Schnell A (1933) Die Weilburger Kettenbrücke. In Land und Lente im Oberlahnkreis, Hirschhäuser, Weilburg, Germany, vol. 9 , no. 11 .

Seelye FB (1935) Resistance of Materials, 2nd edn. Wiley, New York, USA.

Siebert H (1900) Die Nienburger Hängebrücke: Einsturz am 6 Dezember 1825. Paul Schettlers Erben, Cöthen, Germany.

Siebert H (1925) Die Nienburger Hängebrücke in Geschicte und Sage. In Askania: Wochenblattfür Vaterlandische Geschicte, Beitrage zur Cöthenschen Zeitung, Vol. 23, Nos. 24 and 25.

Sim D and Ridge I (2002) Iron for the Eagles: The Iron Industry of Roman Britain. Tempus Publishing, Charleston, SC, USA.

Smith (1836) On Whinstone Constructions, etc. Transactions of the Institute of British Architects of London, John Weale, Sessions 1835-1836, Vol. I, Part I.

Stevenson R (1821) Description of bridges of suspension. The Edinburgh Philosophical Journal 5(10): 237-256.

Stevenson R (1822) Beschreibung der Hängebrücken. In Verhandlungen des Vereins zur Beförderung des Gewerbefleisses in Preussen, (translated by H. Behrnauer) vol. 1, pp 115-127.

Svensson H (2012) Cable-Stayed Bridges. Ernst \& Sohn, Berlin, Germany.

Trapp W (1992) Kleines Handbuch der Masse, Zahlen, Gewichte and der Zeitrechnung. Philipp Reclam, Stuttgart Germany.

Trautwein JC (1874) Civil Engineer's Pocket-Book. Claxton, Remsen \& Haffelfinger, Philadelphia, PA, USA.

Vogel E (1986) Die Geschichte der Stadt Nienburg. Rat der Stadt Nienburg, Nienburg, Germany.

Vogel E (1989) Nienburger Sagen. Betriebsparteiorganisation der SED des VEB Zementwerke Bernburg in Zusammenarbeit mit dem Rat der Stadt Nienburg. Salzlanddruckerei, Strassfurt, Bernburg, Germany.

Wilmers W (2012) Restoration of masonry arch bridges. Proceedings of the Institution of Civil Engineers - Bridge Engineering 165(3): 135-146.

\section{WHAT DO YOU THINK?}

To discuss this paper, please email up to 500 words to the editor at journals@ice.org.uk. Your contribution will be forwarded to the author(s) for a reply and, if considered appropriate by the editorial panel, will be published as discussion in a future issue of the journal.

Proceedings journals rely entirely on contributions sent in by civil engineering professionals, academics and students. Papers should be 2000-5000 words long (briefing papers should be 1000-2000 words long), with adequate illustrations and references. You can submit your paper online via www.icevirtuallibrary.com/content/journals, where you will also find detailed author guidelines. 